Linköping University Medical Dissertation

No. 1614

\title{
Conformational Changes during Potassium-Channel Gating
}

\author{
Jakob Renhorn
}

Department of Clinical and Experimental Medicine Linköping University, Sweden

Linköping 2018 
(C) Jakob Renhorn, 2018

Cover illustration designed by Jakob Renhorn

Published articles and figures have been reprinted with permission of the copyright holders.

Printed in Sweden by LiU-Tryck, Linköping, Sweden, 2018

ISSN 0345-0082

ISBN 978-91-7685-338-2 


\section{To Helena, Elis, \\ Ines, and Benjamin}




\section{Table of Contents}

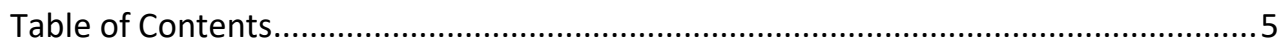

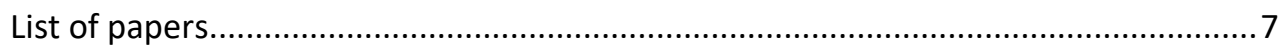

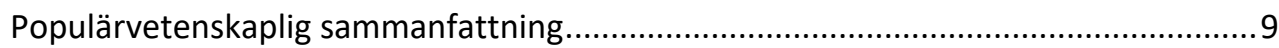

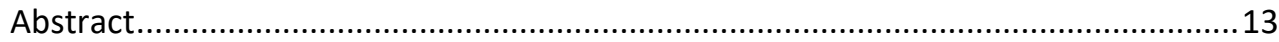

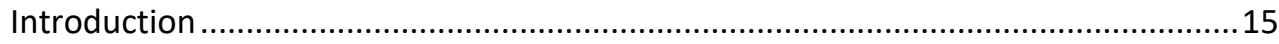

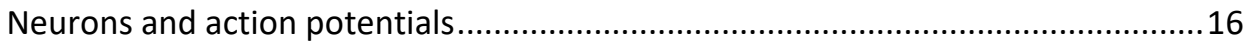

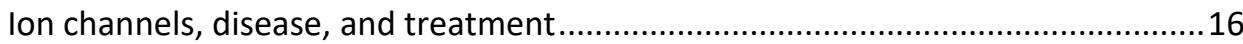

Structure and function of voltage-gated ion channels ..........................................17

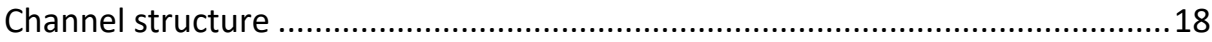

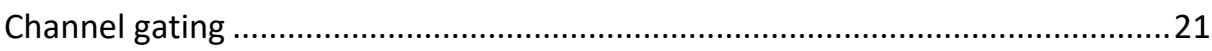

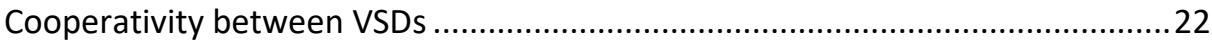

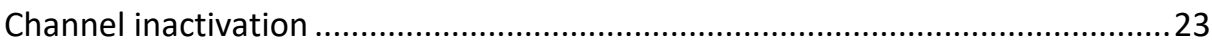

Voltage-sensor movement during inactivation .................................................24

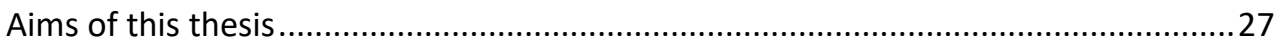

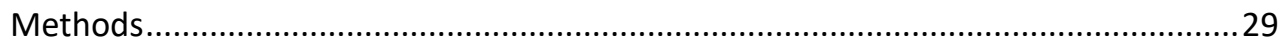

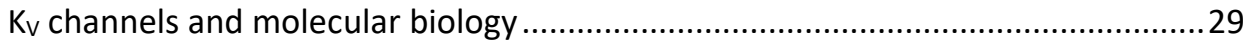

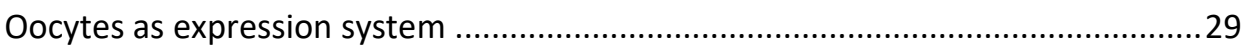

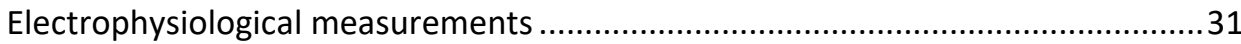

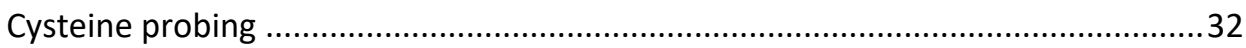

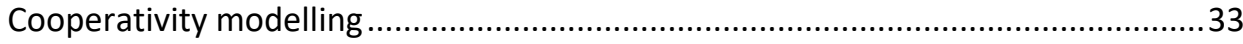

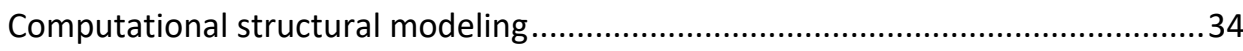

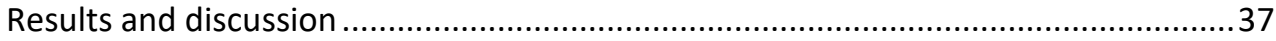

Voltage-sensor movement during channel gating (Paper I and II) ...........................37

$\mathrm{Cd}^{2+}$ interactions suggest a sliding motion of $\mathrm{S} 4$ along S3 ...................................37

Molecular models of the VSD in different states ................................................40

VSDs interact with each other (Paper II) ........................................................... 41

Cooperativity between subunits during channel closure........................................41

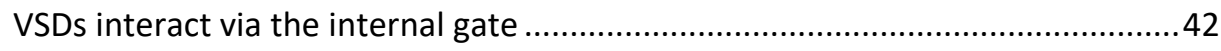

Voltage sensor-to-pore communication during C-type inactivation (Paper III) ........44 
Interactions between the pore and the VSD affect C-type inactivation ...............44

C-type inactivation causes changes to the VSD .............................................. 48

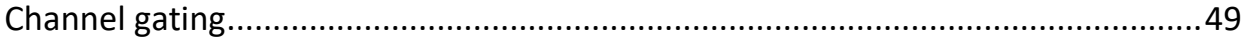

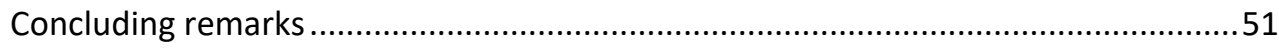

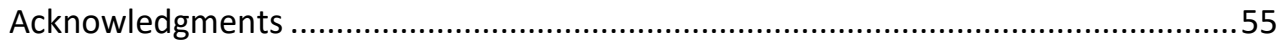

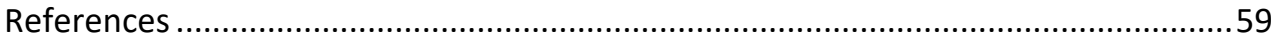




\section{List of papers}

I. Henrion U, Renhorn J, Börjesson SI, Nelson EM, Schwaiger CS, Bjelkmar P, Wallner B, Lindahl E, Elinder F. Tracking a complete voltage-sensor cycle with metal-ion bridges. Proc. Natl. Acad. Sci. U. S. A. 109, 8552-8557 (2012)

II. Renhorn J*, Conti L*, Elinder F. Long-distance cooperativity in the opening transition of a voltage-gated potassium channel. Manuscript.

III. Conti L*, Renhorn J*, Gabrielsson A, Turesson F, Liin SI, LindahI E, Elinder F. Reciprocal voltage sensor-to-pore coupling leads to potassium channel C-type inactivation. Sci. Rep. 6, 27562 (2016).

* These authors contributed equally to this work 


\section{Populärvetenskaplig sammanfattning}

Nervceller är elektriskt ledande celler med förmågan att skicka impulser upp till hundra gånger per sekund. I centrum för denna signalering finns jonkanaler, som släpper in och ut laddade partiklar ur cellen likt slussar som släpper in och ut båtar ur en sjö. Genom att släppa in positivt laddade natriumjoner i nervcellen kan en aktionspotential skapas och genom att släppa ut kaliumjoner så avslutas den och cellen återställs för att återigen kunna skicka en ny aktionspotential. Allt detta ska hinna ske tio gånger under en blinkning. För att åstadkomma så snabb signalering krävs jonkanaler som bara släpper igenom en typ av jon och som kan öppna och stänga snabbt vid mycket små förändringar i laddningen över cellens membran.

En spänningskänslig kaliumkanal består av en central por med fyra omkringliggande spänningssensorer. Poren har en dörr samt en förträngning som endast tillåter att kalium passerar kanalen. Spänningssensorerna har till uppgift att övervaka laddningen över membranet och signalera till dörren att öppna eller stänga kanalen vid behov. Jonkanaler uppvisar ett minne, där kanalen blir svårare att stänga om den har varit öppen länge. Det verkar också som att olika delar av kanalen samverkar, där en del av kanalen påverkas av vad som händer i andra delar. I denna avhandling har vi studerat strukturella förändringar som sker i den spänningskänsliga kaliumkanalen när den öppnar, stänger och kollapsar och hur dessa förändringar påverkar kanalens funktion. Kunskap om kanalens normala funktion är nödvändig för att förstå hur den påverkas av sjukdomsframkallande mutationer. Kunskapen kan också användas som grund vid design av läkemedel för att förändra onormal nervaktivitet som vid epilepsi och kronisk smärta.

Våra studier har visat att spänningssensorns fjärde segment (S4) rör sig utåt när membranets utsida blir negativ, vilket sker vid en aktionspotential. Under denna rörelse stabiliseras S4s positiva aminosyror genom att interagera med negativa aminosyror i spänningssensorns övriga tre segment. S4, som är ansluten till porens dörr, drar upp dörren med denna rörelse och får därmed kalium att flöda genom kanalen. Vi har även visat att det finns en kommunikation mellan kanalens fyra spänningssensorer som gör att spänningssensorerna föredrar att vara aktiverade så länge andra spänningssensorer är aktiverade. Detta leder till att kanalen tar längre tid att stänga när den elektriska spänningen över membranet återställs. Dessutom har vi visat att spänningssensorerna kan påverka porens förträngning och få den att omformas. Omformningen gör att kalium inte längre kan flöda genom poren vilket därmed stänger jonflödet, även om porens dörr är öppen. Till sist har vi visat att porens kollaps påverkar de aktiverade spänningssensorerna så att de blir mindre 
känsliga för förändringar i den elektriska spänningen över membranet, vilket leder till att det tar längre tid att stänga kanalerna.

Vi har visat på strukturella förändringar som sker i kanalen när den öppnar och stänger. Genom att designa läkemedel som binder till områden som är viktiga för kanalens öppning och stängning skulle dessa processer kunna modifieras vilket skulle förändra kanalens funktion och nervcellens aktivitet. Detta skulle kunna användas för att återställa nervcellers signalering när den är förändrad, som vid epilepsi och kronisk smärta. 


\section{Abstract}

Voltage-gated ion channels have a paramount importance in many physiological processes such as cell-to-cell communication, action potential-propagation, and cell motility. Voltage-gated ion channels are characterized by their ability to sense membrane voltage and to greatly change channel activity in response to small changes in the voltage. The ability to sense voltage resides in the four voltage-sensor domains (VSDs) surrounding the central ion-conducting pore. Membrane depolarization causes the inside of the membrane to become positively charged, electrostatically repelling the positively charged fourth transmembrane segment (S4), or voltage sensor, in the VSD, causing the voltage sensor to move outwards. This motion provides necessary energy to open the pore and allow ion conductivity. Prolonged channel activation leads to alterations in the selectivity filter which cease ion conductivity, in a process called slow inactivation. In this thesis, we investigated the movement of $\mathrm{S} 4$ during activation of the channel. We also studied the communication between the four subunits during activation as well as the communication between the pore domain and VSD during slow inactivation.

We have shown that voltage sensors move approximately $12 \AA$ outwards during activation. The positively charged amino acid residues in $\mathrm{S} 4$ create temporary salt bridges with negative counter-charges in the other segments of the VSD as it moves through a membrane. We have also shown that the movement of one of the four voltage sensors can affect the movement of the neighboring voltage sensors. When at least one voltage sensor has moved to an up-position, it stabilizes other voltage sensors in the up-position, increasing the energy required for the voltage sensor to return to the down position.

We have also shown reciprocal communication between the pore domain and the VSDs. Alterations in the VSD or the interface between the pore and the VSD cause changes in the rate of slow inactivation. Likewise, modifications in the pore domain cause changes to the voltage-sensor movement. This indicates communication between the pore and the VSD during slow inactivation.

The information from our work could be used to find new approaches when designing channel-modifying drugs for the treatment of diseases caused by increased neuronal excitability, such as chronic pain and epilepsy. 


\section{Introduction}

The quest to understand human thoughts and emotions has occupied philosophers and scientists for thousands of years. Some of the earliest explanations for the origin of human consciousness, intelligence, and emotions date back to ancient Egypt and Greece.

One of the first people to discover the significance of the brain was Alcmaean of Croton no later than 500 BC. By dissecting animals, he found a channel-like structure connecting the eyes and the brain, likely the optic nerves. Galen of Pergamont (129$216 \mathrm{BC}$ ) could by dissection show that all nerves originate from the spinal cord and the brain, and that the brain and spinal cord were of the same matter. He concluded that all thoughts and voluntary movements originate from the brain. The theory that the center of intelligence is in the brain, the encephalocentric theory, and not the heart, the cardiocentric theory, was also strengthened by the observation of symptoms caused by head injury. The Hippocratic canon describes a woman in whom an incision of the temple caused a spasm in the opposite side of the body. Epilepsy and mental illness were also connected to the brain, even though the illnesses were considered to be caused by an imbalance in humors ${ }^{1-3}$.

The idea that nerve signals are electrical in nature was not postulated until the beginning of the eighteenth century by Sir Isaac Newton. This was shown by the experiments of Luigi Galvani in 1792, in which he caused the contraction of frog muscles using electricity. In 1952, Andrew Huxley and Alan Hodgkin showed that nerve signals, or axonal activity, are caused by the passive diffusion of $\mathrm{Na}^{+}$and $\mathrm{K}^{+}$ across biological membranes and that this diffusion was dependent of membrane voltage. They assumed the presence of pathways through which ions are allowed to cross the membrane, either through aqueous pores or active transporters. This theory earned them the Nobel Prize in 1963. It was later shown that $\mathrm{Na}^{+}$and $\mathrm{K}^{+}$cross a membrane through different ion-specific channels. The first molecular information about ion channels came in the mid-80s, and, by late-90s, the first crystal structure was resolved showing the atomic structure of a $\mathrm{K}$ channel, a discovery earning Roderick MacKinnon the Nobel Prize in $2003^{4,5}$.

Advances have been made in our understanding of channel function since 2003, even so, many aspects remain unknown. In this thesis, we have investigated the structural rearrangements occurring in a voltage-gated $\mathrm{K}\left(\mathrm{K}_{\mathrm{v}}\right)$ channel during the opening and closing of the channel and the interplay between the different segments and subunits during the activation and inactivation of the channel. 


\section{Neurons and action potentials}

Neurons are highly asymmetrical cells that are electrically and chemically excitable with receptive dendrites at one end and a transmitting axon at the other. Ion channels and receptors are central to cellular excitability. Alterations in membrane voltage can be generated by regulating ion flow across a membrane.

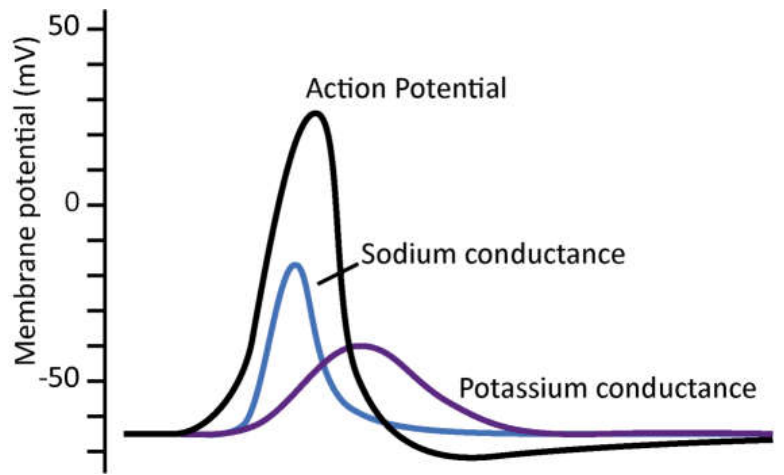

Figure 1. Sequential opening of voltage-gated sodium and potassium channels initiates and terminates the action potential ${ }^{6}$. An action potential is initiated by the activation of the fast opening voltage-gated $\mathrm{Na}$ channels, causing membrane depolarization. The subsequent recruitment of slowly opening $\mathrm{K}$ channels, repolarize membrane voltage, causing hyperpolarization.

An action potential is initiated when the membrane voltage at the axon initial segment reaches about -50 mV (Fig. 1). Reaching this threshold causes voltage-gated $\mathrm{Na}$ (Nav) channels to open rapidly and, thereby, allow influx of $\mathrm{Na}^{+}$ions, causing an additional increase in membrane voltage. This causes additional Nav channels to open, resulting in a self-amplifying cascade of Nav-channel opening. This gives rise to a sharp increase in membrane voltage (i.e. inside potential more positive than the outside). The action potential is terminated by the fast inactivation of the Nav channels and by the opening of $K_{v}$ channels, which slowly activate during depolarization. The activation of $\mathrm{K}$ channels allows for the efflux of $\mathrm{K}^{+}$, causing the repolarization of the membrane to a more negative voltage, even more negative than normal resting voltage. The combined effect of repolarization and Nav-channel inactivation makes subsequent depolarizations during the absolute refractory period impossible, limiting the action potential frequency and preventing backward propagation of the action potential in the axon ${ }^{6-8}$.

\section{Ion channels, disease, and treatment}

$K_{v}$ channels play a pivotal role in setting resting-membrane voltage and modulating action-potential duration and discharge patterns. Disruption of the channel function, 
caused by genetic alterations, immunological reactions, or drugs, can cause neuronal dysfunction that may be painful, debilitating, or even deadly.

Mutations in the Kv1.1 subfamily may cause episodic ataxia type 1 in humans. These mutations cause a reduction in channel expression, voltage sensitivity, or an increase in C-type inactivation. Episodic ataxia type 1 is an autosomal dominant disorder that is characterized by stress-triggered quivering or muscle spasms lasting from seconds to minutes ${ }^{9,10}$.

Mutations in Kv11.1 (hERG) and Kv7.1 (KCNQ1) channels can result in deficient channel trafficking, accelerated deactivation, or reduced voltage sensitivity. The deficiencies cause a reduction of the repolarizing current which leads to delayed or prolonged repolarization of the ventricle, called Long QT syndrome. This may cause episodes of abnormal heart beats leading to fainting, ventricular fibrillation, or even cardiac arrest ${ }^{10-12}$.

An increase in knowledge regarding channel activation, deactivation and inactivation, and the molecular basis behind channel gating may aid in the development of pharmaceuticals that restore channel function and treat channelopathies.

\section{Structure and function of voltage-gated ion channels}

Several hundred genes of ion channels have been found since the development of protein chemistry and molecular biology in the mid-80s. Voltage-gated ion channels form one of the few channel superfamilies, to which voltage-gated $\mathrm{K}-$, $\mathrm{Na}-$, and $\mathrm{Ca}$ channels belong. Channels within this superfamily share some common features such as a central aqueous ion-conducting pore that is surrounded by four voltage sensor domains (VSD). These channels share the basic function in which VSDs undergo structural rearrangements during depolarization, which lead to the opening of the ion-conducting pathway ${ }^{5,6}$.

Different channels have differences in structure and function. $K_{v}$ channels are formed by the assembly of four identical or different subunits, where all subunits influence all aspects of gating and inactivation. Nav channels are assembled by four subunits formed from one single monomer. The different voltage-gated cation channels also have slight structural differences in selectivity filter, which allows the conductance of specific ions and exclusion of others.

Even $K_{v}$ channels have functional and structural diversity. Some $K_{v}$ channels open within a few milliseconds while others require almost a second to open, some 
inactivate fast while others inactivate slowly, and some bind auxiliary subunits while others do not.

In this work, we chose to study the Shaker Kv channel. The Shaker channel was discovered in the late 80s in mutant fruit flies that shook their legs while under ether anesthesia. The mutant flies lacked the fast transient $\mathrm{K}$ current in presynaptic terminals, causing a delayed repolarization and increased neurotransmitter release. The subsequent screening for channels similar to the Shaker channel resulted in the discovery of several related channel families as well as Shaker sub-type channels. In mammals, all Shaker-related channels, or Kv1 channels, are expressed in the axon or nerve terminal. The channels are formed by the assembly of four subunits within the $\mathrm{K}_{\mathrm{v} 1}$ subfamily but never with subunits from related subfamilies ${ }^{5,9}$.

The Shaker channel is a prime candidate for the study of voltage-gated ion-channel function due to the amount of structural and functional information available. The open state conformation is known at atomic resolution for a Shaker like channel, and many aspects of channel gating are known from electrophysiological studies. The channel is also relatively easy to manipulate and results are straight forward to interpret, due to the channels four-fold symmetry. Even so, many aspects remain unknown regarding the molecular motions occurring within the Shaker channel during activation, deactivation and inactivation as well as the communication between subunits and domains.

\section{Channel structure}

$K_{v}$ channels are composed of four subunits that form a central ion-conducting pore surrounded by four VSDs (Fig. 2A, B). Each subunit consists of six transmembrane segments denoted S1-S6 where S1-S4 form the peripheral VSDs and S5-S6 of all four subunits collectively form the central ion-conducting pore (Fig. 2C) ${ }^{13-15}$.

The selectivity filter, located at the outer mouth of the pore, gives the channel its $\mathrm{K}^{+}$ specificity (Fig. 2B) ${ }^{16-18}$. The positively charged $\mathrm{K}^{+}$attracts the polar water molecules in solution, creating a water shell that surrounds the ion. In order for $\mathrm{K}^{+}$to gain access to the narrow selectivity filter, it must shed most of its water molecules in an energetically unfavorable process. The interactions with water are replaced with electrostatic interactions with the polar or charged amino acid residues that line the inside of the selectivity filter (Fig. 2D). $\mathrm{K}^{+}$can traverse the selectivity filter since its interactions within the selectivity filter compensate for those lost during water shedding, thereby creating a low energy barrier. 
The selectivity filter consists of several crucial and highly conserved amino acid residues. In $\mathrm{K}_{\mathrm{v}}$ channels, these interactions are formed by the TVGYG motif from each subunit, oriented with their carboxyl group pointing into the ion conducting pathway that creates four $\mathrm{K}^{+}$binding sites. Only two sites can be occupied at any given time (Fig. 2D).
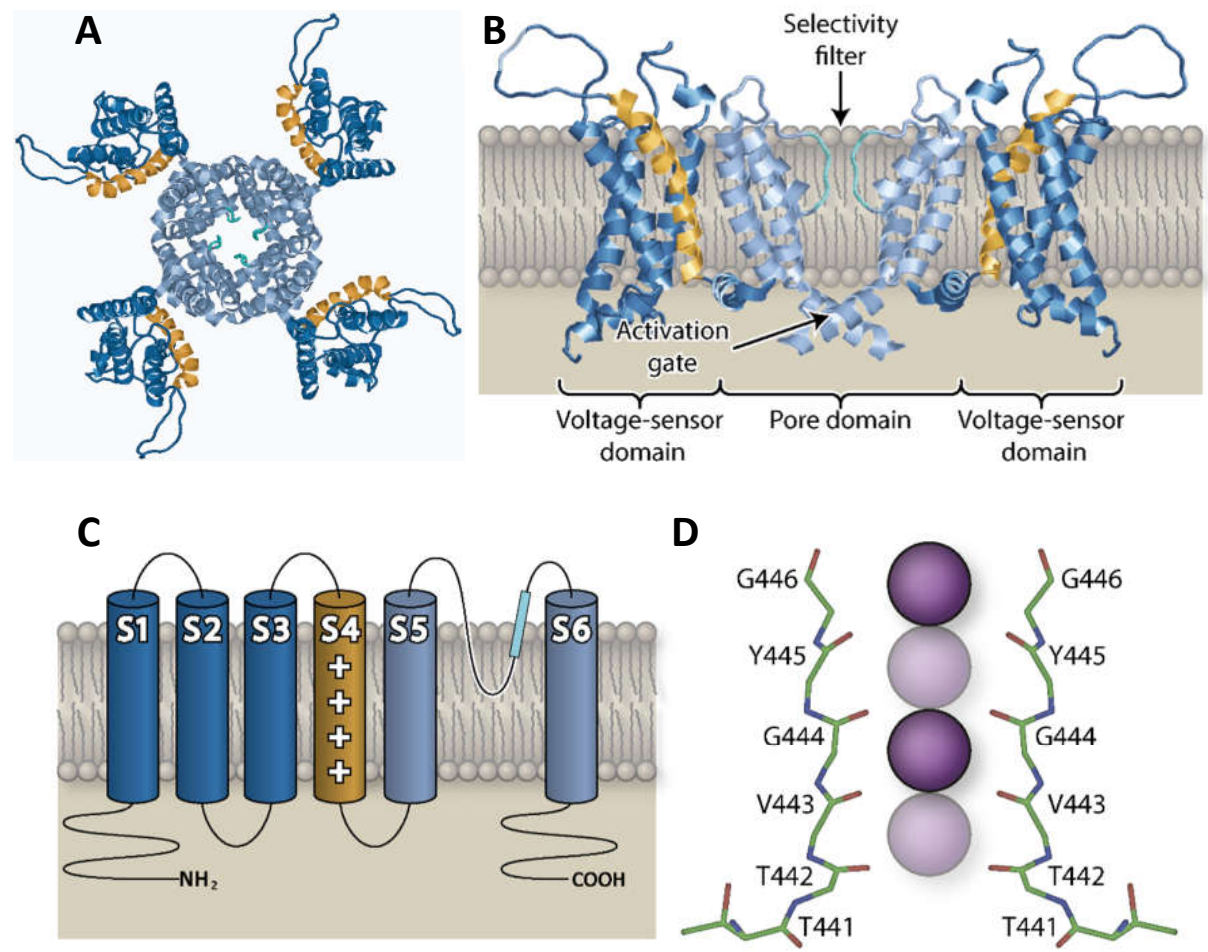

Figure 2. Molecular structure of the Shaker $K_{v}$ channel. (A) Top view of the central ion-conducting pore surrounded by four VSDs. (B) Side view of the Shaker channel. (C) Cartoon showing the six transmembrane segments of one subunit. Segments 1-4 (S1-S4) form the VSD and segments 5 and 6 (S5-S6) of all four subunits form the ion-conducting pore. (D) The selectivity filter of the Shaker channel. In panels A-C: VSDs shown in dark blue, S4 in yellow, pore domain in light blue and selectivity filter in cyan. In panel $\mathrm{D}: \mathrm{K}^{+}$shown as purple spheres.

The smaller $\mathrm{Na}^{+}$has a larger water shell due to its more localized charged and stronger electric field. The pore of the $\mathrm{K}_{\mathrm{v}}$ channel is too large for the small $\mathrm{Na}^{+}$to interact efficiently with the carboxyl groups of the selectivity filter to facilitate water shedding. This results in a high energy barrier to the $\mathrm{Na}^{+}$entering the selectivity filter. The $\mathrm{K}_{\mathrm{v}}$ channel, therefore, has a 100 -fold higher selectivity for $\mathrm{K}^{+}$over $\mathrm{Na}^{+}$. The selectivity filter is stabilized by the surrounding pore and the $K^{+}$in the filter itself ${ }^{19,20}$. Disruption of the stability of the selectivity filter results in alterations in its structure, 
which destroys the $\mathrm{K}^{+}$binding sites and ultimately renders the ion channel nonconductive in a process called C-type inactivation ${ }^{20,21}$.

The activation gate is located on the intracellular side of the pore, separated from the selectivity filter by a water-filled vestibule (Fig. 2B). The gate is composed of the S6 of all four subunits, which cross each other, causing their side chains to physically occlude the pore in the closed state. The gate opens with a slight bending at a hinge in S6 when electromechanical tension from the voltage sensor is released. The hinge contains amino acid residues giving the helix the necessary flexibility to bend during gating, thereby opening and closing the channel. The flexibility of the helix is attributed either to a glycine at position $466^{22-24}$ or the proline-containing PVP motive at position $473-475^{23}$. The importance of these residues are different in different channels. The glycine at position 466 is essential for Shaker gating, where the substitution of the residue to almost any other residue renders the channel unable to open ${ }^{22}$. The glycine in the BK and hERG channel is, on the other hand, nonessential ${ }^{25}$. Substitution of the glycine for alanine still produces channels capable of opening, at more positive voltages for the BK channel and more negative ones for the hERG channel. This position is also important in the KCNQ channel, but there the glycine is replaced with an alanine $22,23,25$. The PVP motif at position $473-475$ is also important for gate opening in the Shaker channel ${ }^{26,27}$. This motif creates a flexible bend in $\mathrm{S} 6$ that allows it to bend during gating, causing the gate to open or close. This motif is also important in the KCNQ channel but it is replaced with a PAG motif instead of a PVP motif ${ }^{23}$. The opening of some channels such as hERG and KCNH are not dependent on the bending at this position since they completely lack this motif ${ }^{28}$.

The importance of the different motifs varies between channels. This suggests that the mode of opening the gate is not identical for all channels. The activity of some channels is modulated with auxiliary subunits, ligands, pressure, or temperature. Channels can also vary greatly in the time course of gating and inactivation. It is, therefore, not surprising if the channels also have different modes of opening the gate.

The VSD is an hourglass-shaped complex located in the periphery of the pore assembled with S1-S4 in each subunit. Positively charged residues in the voltage sensor (S4) are displaced when the membrane voltage changes, resulting in voltagesensor movement. The motion of the voltage sensor is transferred via the S4-S5 linker to the gate, opening or closing the ion-conducting pathway. The other segments of the VSD provide support and counterchanges for the positive charges in the voltage sensor, creating a low-energy environment for the voltage sensor as it 
moves through the membrane. Each VSD carries an intracellular $\mathrm{N}$-terminal inactivation element, called a "ball and chain". This element diffuses into the gate of the channel upon activation, physically occluding the channel in a process called fastor N-type inactivation ${ }^{29}$.

\section{Channel gating}

Displacement of charges within the VSD is essential for voltage sensing. The voltage sensor carries several positively charged residues, called gating charges, where the first five residues ( $R 1, R 2, R 3, R 4$, and $K 5$ ) contribute the most to the gating charge movement $^{30,31}$.

During depolarization, the outside of the membrane becomes more negative than the inside. The positive charges in the voltage sensor are electrostatically repelled by positively charged inside of the membrane. This causes the voltage sensor to travers a considerable distance outwards through several stable intermediate states until it reaches its most outward primed position (Fig. 3b) ${ }^{13,32-34}$. The positive charges in the voltage sensor temporarily form salt bridges with countercharges in S1,S2, and S3 during gating, which reduces the energy required to transverse the membrane ${ }^{14,33,35}$. The four voltage sensors move independent of each other until they reach an upposition, this is followed by a channel-opening cooperative transition ${ }^{36,37}$. The motion of the voltage sensor releases the asserted force on the gate, causing $\mathrm{S} 6$ to bend and,

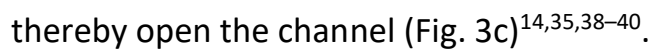

Repolarization causes the inside of the membrane to become negative. The positively charged voltage sensor is electrostatically attracted to the inside of the membrane, causing the voltage sensor to return to its down-position. This reestablishes the force applied to the gate, straightening the hinge in S6 and, closing the gate (Fig. 3a) ${ }^{14,35,38-40}$. 


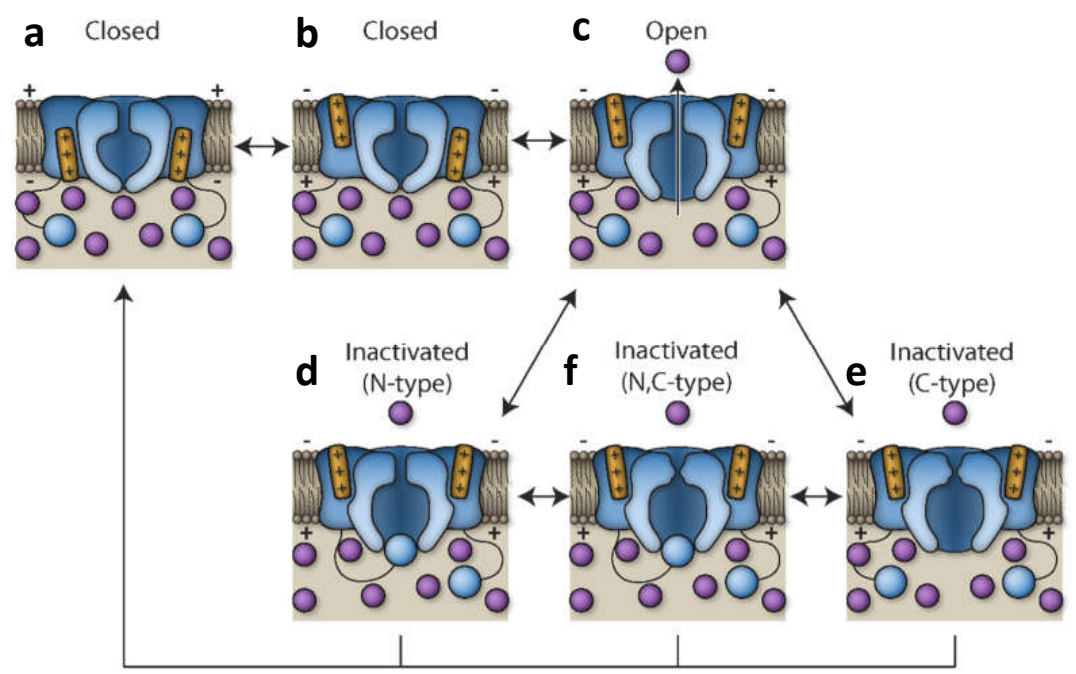

Figure 3. Gating of the $\mathrm{K}_{\mathrm{v}}$ channel. The channel is closed at hyperpolarized voltages, with its voltage sensors in a down-position (a). Upon depolarization, the voltage sensors independently transvers several intermediate steps to reach an up-position (b). The internal gate opens after a final cooperative transition (c). The channel inactivates fast by the physical occlusion of the pore by the inactivation particle in a process called $\mathrm{N}$-type inactivation (d). The channel is inactivated slowly due to structural rearrangements of the selectivity filter leading to ceased ion conductivity, in a process called C-type inactivation (e). The channel can be both $\mathrm{N}$ - and C-type inactivated at the same time (f). Inactivated channels recover when the membrane hyperpolarizes and the channel closes ( $\mathrm{d}-\mathrm{f}) . \mathrm{K}^{+}$ is shown as purple spheres and $\mathrm{S} 4$ as yellow rods.

\section{Cooperativity between VSDs}

The voltage sensors move from a down state to an up-state, passing several metastable intermediate states as it moves through the VSD during depolarization ${ }^{41-}$ ${ }^{43}$. The four voltage sensors can move independent of each other, permitting the voltage sensors to take different positions at any given time (Fig. 4A,B) ${ }^{36,44}$. However, channel opening has also been associated with a concerted or highly positively cooperative step ${ }^{37,38}$. Positive cooperativity means that a molecular rearrangement in one subunit supports the equivalent rearrangement in a second subunit, which in turn further supports the rearrangement in a third and so on (Fig. 4C). This means that the intermediate states are unstable and unfrequently occupied. If this positive cooperativity engage the four voltage sensors, this means that all of them either can be in an up-state or in a down state, but not in any intermediate configurations (Fig. $4 C, D)$. However, cooperativity can engage the pore domain and gate opening rather than the voltage-sensor transitions. Interaction between subunits is an important determinant of normal channel gating, not only in $\mathrm{K}_{\mathrm{v}}$ channels but also in Cav channels and even Nav channels ${ }^{45}$. Disruption of cooperativity causes a decrease in 
voltage dependence as well as a shift in the conductance-vs-voltage $(G(V))$ curve in the positive direction along the voltage axis ${ }^{41}$.

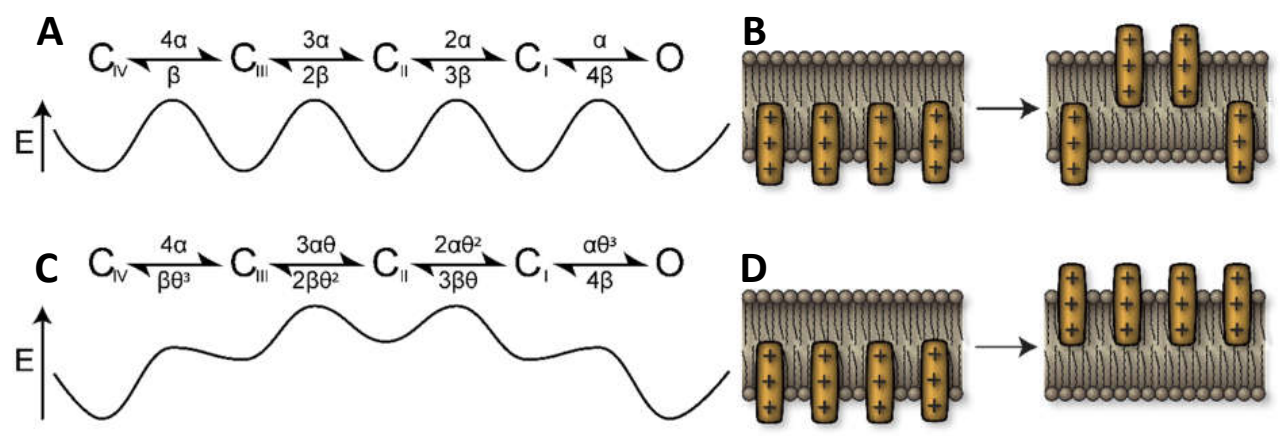

Figure 4. Cooperative and non-cooperative gating models. (A) A non-cooperative kinetic model (top) and corresponding schematic energy diagram (bottom). All states are about equally stable. (B) In the non-cooperative model the voltage sensors move independent of each other and there are stable combinations of up and down states. (C) A cooperative kinetic model (top) and corresponding schematic energy diagram (bottom). The intermediate states are unstable. (D) If cooperativity engages the voltage sensors, then the voltage sensors effectively move together in a concerted step.

\section{Channel inactivation}

Many $\mathrm{K}_{\mathrm{v}}$ channels are inactivated on a millisecond timescale by the blockage of the pore by an $\mathrm{N}$-terminal inactivation particle or inactivation gate. This is done, through a mechanism called fast- or $\mathrm{N}$-type inactivation. Channel opening causes the ball to diffuse into the internal mouth of the channel, physically blocking the ion conduction pathway and rendering the channel non-conductive (Fig. 3d). Inactivation can be sped up by shortening the chain length, slowed down by reducing the number of balls, or eliminated by removing the balls altogether ${ }^{29,46,47}$.

$\mathrm{K}_{\mathrm{v}}$ channels have a second type of inactivation that is distinctively different from $\mathrm{N}$ type inactivation in both time course and inactivation mechanism. This slow- or Ctype inactivation occurs on a second time scale that can only be seen when fast inactivation has been removed. In this work, this was done by deleting nucleotide 6 through 46 in the so called Shaker-IR channel ${ }^{29}$. With fast inactivation removed, prolonged depolarization causes structural rearrangements in the selectivity filter, which eliminates the ability of the selectivity filter to complex and conduct $\mathrm{K}^{+}$, thus rendering the channel non-conductive (Fig. 3e) ${ }^{21,48}$. There are two major hypotheses for how the structural rearrangements in the selectivity filter lead to a loss of ion conductivity: First, it could be caused by a pinching in the center of the selectivity filter that could render the selectivity filter too narrow for $\mathrm{K}^{+}$conductivity ${ }^{21,49,50}$. Second, it could be caused by a dilation of the external mouth of the selectivity filter that disrupt $\mathrm{K}^{+}$coordination and correct water shedding, resulting in a high energy 
barrier to $\mathrm{K}^{+21,51,52}$. The two postulated mechanisms alone or in combination in different parts of the filter could lead to a non-conducting channel. There is also the possibility that the mechanisms have different degrees of importance in different types of $\mathrm{K}$ channels. There is cooperativity between subunits during slow inactivation, in which all four subunits must make a transition after channel opening in order for the rearrangements in filter to occur ${ }^{53,54}$.

\section{Voltage-sensor movement during inactivation}

The movement of the voltage sensors during gating gives rise to a current known as a gating current ${ }^{55,56}$. Gating currents are small and can only be measured when ion conductivity has been eliminated or greatly reduced either by pore blockage, by mutations that closes the gate, or by eliminating the conducting ion $^{5,57-59}$.

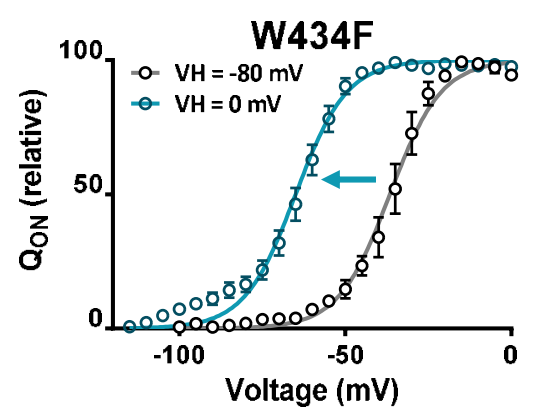

Figure 5. Gating charge movement is dependent on holding voltage. The gating charge movement is dependent on holding voltage. Holding the channel at a depolarized voltages for prolonged periods causes a shift in the gating charge vs voltage relationship towards negative voltages.

The relationship between gating charge movement and voltage, the $\mathrm{Q}(\mathrm{V})$ relationship, shifts in the negative direction along the voltage axis when the channel is held at a depolarized voltages for prolonged periods of time (Fig. 5). The shift in the $Q(V)$ relationship is known as mode-shift, and it indicates a change in the energy landscape during inactivation that forces the charge movement to take an alternative kinetic pathway when $\mathrm{S} 4$ returns to a down position. The voltage sensor, therefore, requires stronger repolarization to return to its resting position and close the gate after long depolarization than after short ${ }^{60-63}$. This could either be due to an increase in the resistance in the downward movement of the voltage-sensor, an increase in resistance to close the internal gate, or both. Mode-shift has been demonstrated in $\mathrm{K}^{58,64}, \mathrm{Na}^{65,66}$, and $\mathrm{Ca}^{67}$ channels as well as in the hyperpolarization-gated cation channels $(\mathrm{HCN})^{62}$. Mode shift has been suggested to play an important role in normal heart beat frequency ${ }^{62}$, the regulation of cellular excitability ${ }^{68}$, and temperature sensitization ${ }^{69}$. 
Mode-shift occurs in some systems where there is no slow inactivation, such as in the voltage-dependent phosphatase (Ci-VSP) that lacks a pore and, therefore, also slow inactivation ${ }^{70}$. Mode-shift can also be found in the $\mathrm{pH}$-sensitive $\mathrm{K}$ channel (KcsA) which lacks VSDs ${ }^{63}$. The mode-shift seems to be an intrinsic property of both the pore and the VSD in these isolated systems. A link between slow inactivation and mode-shift has been suggested in the Shaker channel since inactivation and modeshift have the same time course ${ }^{60}$. On the other hand, the T449V/1470C mutation eliminates the inactivation of the channel, possibly by entering a kinetically different open state without eliminating the $Q(V)$ shift ${ }^{58}$. Mode-shift is also eliminated by uncoupling the link between the pore domain and the VSD ${ }^{71}$. These experiments shows that there is a link between pore opening and mode-shift, and that inactivation might not even be a prerequisite for mode-shift. The mechanism behind mode-shift in the Shaker channel could therefore be different from that of both the Ci-VSP and KcsA. 


\section{Aims of this thesis}

The aim of this thesis was to investigate the structural rearrangements that occur in a Kv channel when the channel is activated, deactivated and inactivated. The specific aims were:

1. How does the voltage sensor move during gating?

2. Is there any cooperativity between subunits in the final voltage-sensor transition?

3. Is there any communication between the voltage-sensor domain and the pore on the extracellular side?

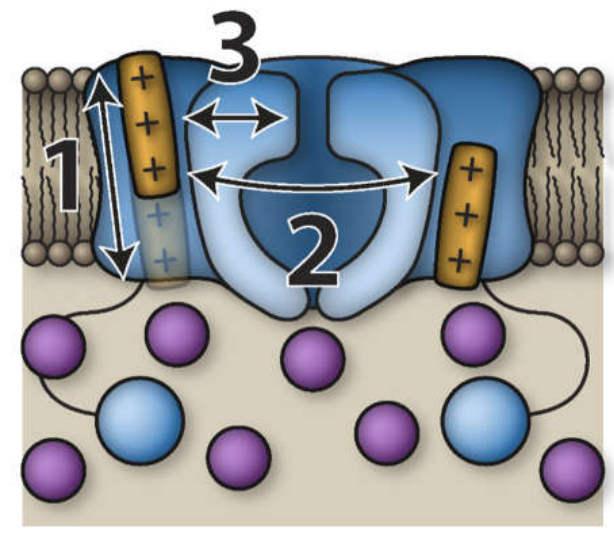

Figure 6. Processes investigated in this thesis. In this thesis, we investigated voltage-sensor movement during gating (1), cooperativity between subunits in the final voltage-sensor transition (2), and communication between the voltage-sensor domain and the pore on the extracellular side (3). 


\section{Methods}

\section{$K_{v}$ channels and molecular biology}

All experiments were performed on the Shaker $\mathrm{H} 4 \mathrm{~K}_{\text {channel }}{ }^{72}$, which was made incapable of fast inactivation by the $\Delta(6-46)$ deletion ${ }^{29}$, inserted into the Bluescript II $\mathrm{KS}(+)$ vector. This channel is referred to as the wild-type Shaker throughout this thesis. Mutations were introduced using the QuikChange Site-Directed Mutagenesis kit (Agilent Technologies, Santa Clara, CA) and verified with sequencing. Concatemers were created in order to study channels composed of subunits with two different sequences. Concatemers were constructed by the introduction of two consecutive channels into the Bluescript vector. First, the Ndel restriction site was introduced into the beginning or the end of the channel sequence and, thus, replaced the existing Ncol restriction site or amino acid 657 (Fig. 7a). Second, mutations were introduced into the two monomers. Third, the vector was cut using either Ncol and Ndel, or Ndel and EcoRI restriction enzymes (New England BioLabs, Ipswich, MA) (Fig. 7b). Finally, the DNA fragments were inserted into an empty vector using the T4 ligation kit (ThermoFisher, Waltham, MA) (Fig. 7c). Ligation was confirmed with gel electrophoresis and sequencing. The final vector contained two subunits with possibly different sequences. Channels formed from the concatemers contained two subunits of each sequence (Fig. 7d). All monomeric and dimeric DNA was transcribed into RNA using the mMessage mMachinge T7 kit (Ambion, Austin, TX).

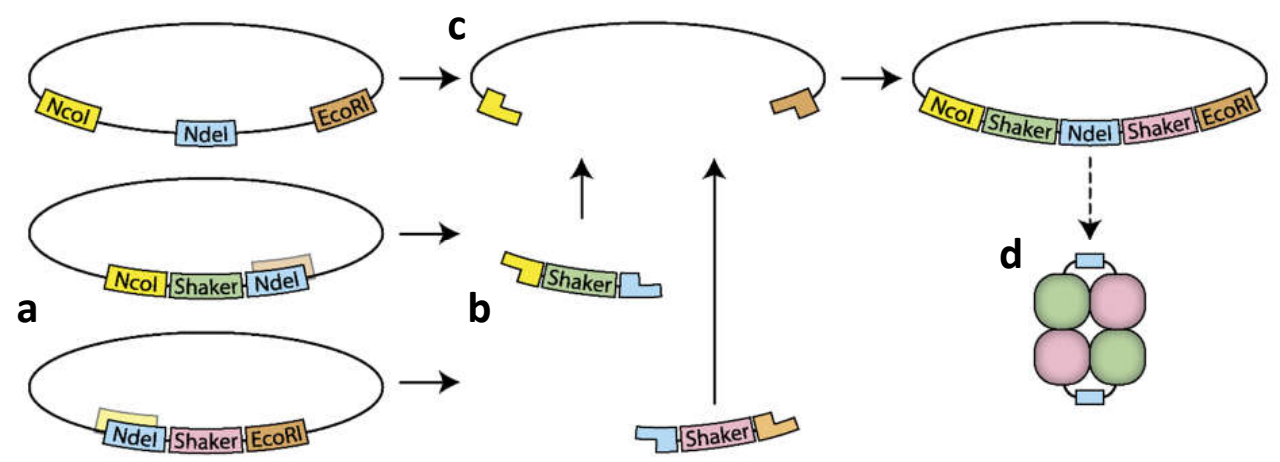

Figure 7. Construction of concatemers. Ndel restriction site was introduced into channel vector (a). Channel sequence was cut and purified (b). Channel fragments were inserted into an empty vector (c). Translated channels consisted of two subunits of each sequence (d).

\section{Oocytes as expression system}

Channels were studied in oocytes from the African clawed frog, Xenopus leavis. The Xenopus oocyte is one of the most widely used expression systems for ion-channel research because of its many advantages. The relatively large size ( 1.1 $\mathrm{mm}$ ) of the oocytes makes the injection of cRNA and electrophysiological measurements easy. 
The oocytes are adapted to be released into an adverse environment in nature, and the oocytes are, therefore, not dependent on the absorption of nutrients for protein synthesis or sustained life. The oocytes also translate injected cRNA into channels in high numbers and traffic them efficiently to the cell membrane. The cell membrane of the oocyte has few endogenous channels that are activated the voltage ranges at which most studies are usually conducted, resulting in little to no interference with the current of the studied channels ${ }^{73}$.

Oocytes were injected with channel coding cRNA and incubated for three to ten days at $8^{\circ} \mathrm{C}$ in MBS to allow channel expression. Oocytes expressing double cysteine mutant channels were incubated in $0.5 \mathrm{mM}$ Ditiotreitol (DTT)-containing solution to prevent spontaneous disulfide bridge formation. Experiments were performed in $1 \mathrm{~K}$, $100 \mathrm{~K}$ or $100 \mathrm{Rb}$ solution with or without $10 \mu \mathrm{M} \mathrm{Cd}^{2+}$. For more details regarding frog surgery and solutions, see paper II. 


\section{Electrophysiological measurements}

Studying the function of voltage-gated ion channels requires an experimental procedure in which membrane voltage $\left(V_{m}\right)$ can readily be controlled and the current over the membrane precisely measured. In this work, the Two-electrode voltage clamp (TEVC) technique was used to study channel function. TEVC uses two electrodes inserted into the oocyte in order to clamp the membrane voltage and record membrane current (Fig. 8).

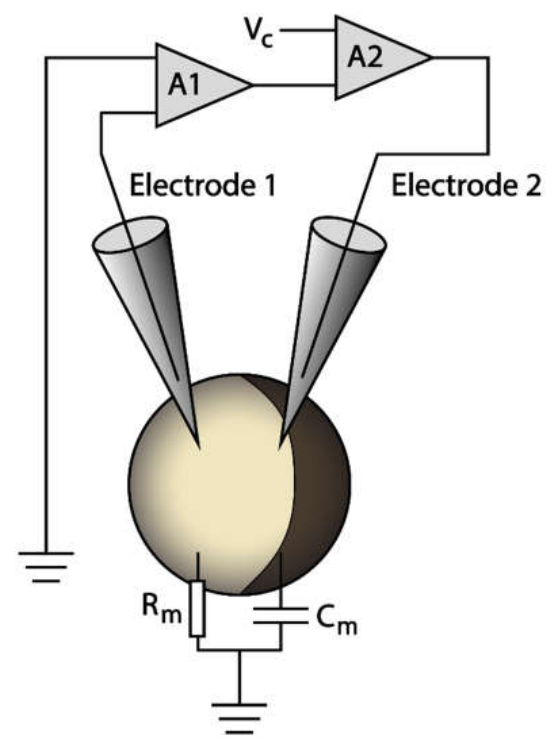

Figure 8. The basic principles of the two-electrode voltage clamp (TEVC) technique. The TEVC technique utilizes two electrodes inserted into the oocyte where one electrode monitors voltage (electrode 1) and the other injects and records current (electrode 2). The voltage follower is denoted as $A 1$, the clamp amplifier as $A 2, V_{c}$ is the voltage command, $R_{m}$ is the membrane resistance and $C_{m}$ is the membrane conductance.

$V_{m}$ is monitored by the voltage electrode (electrode 1 ) connected to the voltage follower (A1). The output of the voltage follower, which is equal to $V_{m}$, is transmitted to the input of the clamp amplifier (A2). The clamp amplifier compares the difference between the present $V_{m}$ and the voltage command signal $\left(V_{c}\right)$. The output voltage of A2 forces a current proportional to the difference between $V_{m}$ and $V_{c}$ through the current electrode (electrode 2 ) into the cell. The current flowing through electrode 2 counteracts all current flowing through ion channels, which gives an exact measurement of membrane current ${ }^{74}$.

The membrane of the oocyte functions as a capacitator $\left(\mathrm{C}_{\mathrm{m}}\right)$ where a dielectric gap separates the charges on the inside and outside of the membrane. The capacitance 
of the membrane creates a voltage difference across the membrane when charged. The current injected into the oocyte to charge the membrane causes a spike in the recording, called capacitive current. The membrane works not only as a capacitator but also as a resistor $\left(R_{m}\right)$, influencing the shape of the capacitive spike.

Opening kinetics and steady-state currents were measured by pulsing from a resting membrane voltage of $-80 \mathrm{mV}$ to a series of membrane voltage ranging from -80 to $+150 \mathrm{mV}$ for $100 \mathrm{~ms}$ or 1 second, depending on the channel opening rate. Steadystate currents were measured on the plateau of ionic currents, and the conductance was calculated according to the electrochemical driving force for $\mathrm{K}^{+}$as depicted by:

$$
G(V)=I_{K} /\left(V-V_{\text {rev }}\right)
$$

The shift in the voltage versus conductance dependences was defined by shifts in the midpoint of a fitted Boltzmann curve. Opening, closing and inactivation time constants were calculated by fitting an exponential curve to the ionic current.

\section{Cysteine probing}

Structural information about the channel was acquired by the creation of metal ion bridges between introduced cysteine residues. Two cysteines were introduced into the VSD: one into the voltage sensor (S4) and one into the surrounding VSD. If the two residues are close at any point during gating, $\mathrm{Cd}^{2+}$ bridge will form between the residues in the presence of $\mathrm{Cd}^{2+}$ in the solution. The formation of a bridge between the two residues will alter channel gating. If the residues are close to each other when $\mathrm{S} 4$ is on the intracellular side, i.e. closed state, the metal-ion bridge will have to be broken in order for $\$ 4$ to move to the extracellular side of the membrane and thereby open the channel. The channel, therefore, requires more energy and stronger depolarization to open. This results in a positive G(V) shift (Fig. 9A) and slowed down opening (Fig. 9B). 

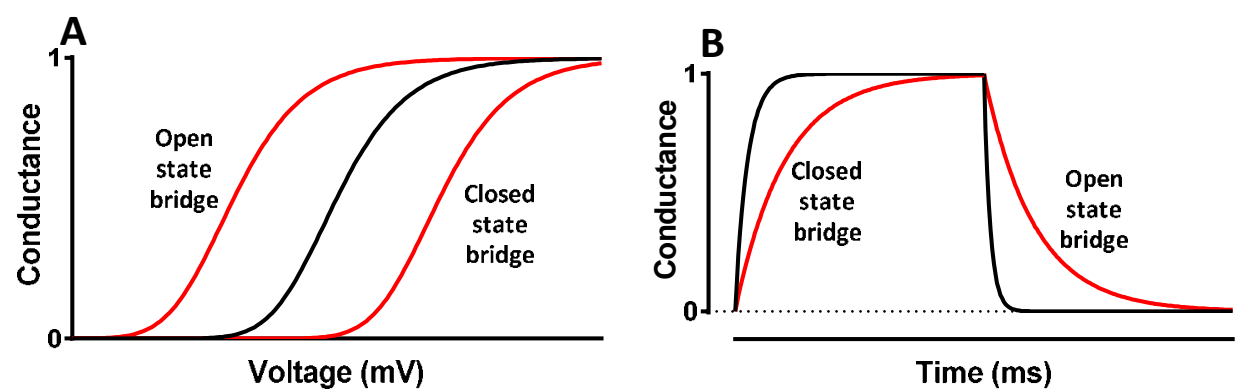

Figure 9. $\mathrm{Cd}^{2+}$ induced effect on double cysteine mutants. (A) $\mathrm{Cd}^{2+}$ bridge formation will theoretically cause a shift in the positive direction (right) of the conductance-vs-voltage curve along the voltage axis if formed in the closed state and in the negative direction (left) if formed in the open state. (B) $\mathrm{Cd}^{2+}$-bridge formation will theoretically cause a reduction in the opening rate if formed in the closed state and a reduction in the closing rate if formed in the open state.

If a $\mathrm{Cd}^{2+}$ bridge forms when $\mathrm{S} 4$ is on the extracellular side when the channel is open, the $\mathrm{Cd}^{2+}$ bridge will have to be broken in order for $\mathrm{S} 4$ to move to the intracellular side and close the channel. The channel, therefore, requires more energy and stronger hyperpolarization to close. This results in a negative $\mathrm{G}(\mathrm{V})$ shift (Fig. 9A) and a slowed down closing (Fig. 9B). Gating kinetics remain unchanged if the residues are not in proximity at any point during gating.

\section{Cooperativity modelling}

Cooperativity is caused by interactions between subunits that causes the movement of one $\mathrm{S} 4$ to be affected by the position of the neighboring S4s. If there is no cooperativity, the movement of the $\mathrm{S} 4 \mathrm{~s}$ will be independent of each other. The closing rate of a channel will, in this case, be the sum of the closing rates of all the S4s the channel is composed of, according to:

$$
k_{\text {non-coop }}(n)=n k_{w t} / 4+(4-n) k_{m u t} / 4 \text {, }
$$

where $n$ is the number of wt subunits, and 4- $n$ is the number of mutant subunits. $k_{w t}$ is the rate for the channel closure of the wt channel and $k_{\text {mut }}$ is the rate for the channel closure of the mutant channel.

In contrast, if there is cooperativity between the subunits, the closing rate of one S4 will be affected by the closing rate of its neighbors, according to:

$$
k_{\text {coop }}(n)=k_{w t} *\left(k_{m u t} / k_{w t}\right)(4-n) / 4 \text {. }
$$

where $\mathrm{n}$ is the number of wt subunits, and 4- $\mathrm{n}$ is the number of mutant subunits. $\mathrm{k}_{\mathrm{wt}}$ is the rate for the channel closure of the wt channel, and $k_{\text {mut }}$ is the rate for the channel closure of the mutant channel. 
Valence of the opening $\left(z_{\alpha}\right)$ or closing $\left(z_{\beta}\right)$ kinetics were determined from

$$
\tau=\tau(0) \exp (V z F /(R T)),
$$

where $\tau(0)$ is the predicted time constant at $0 \mathrm{mV}, V$ is the absolute membrane voltage, and $z$ is either $-z_{\alpha}$ or $z_{\beta}$, depending on the pulse protocol. $F, R$ and $T$ have their normal thermodynamic significances. The sum of $z_{\alpha}$ and $z_{\beta}$ is called $z_{\text {toto }}$.

\section{Computational structural modeling}

Computational modeling is the simulation of the structure and function of biological macromolecules such as membrane proteins, as well as biological processes such as protein folding and ligand binding. The simulation results in detailed molecular structures of the simulated macromolecule or process. The protein being simulated and a representative part of its environment, such as a membrane, water, and ions, are included in the modeling. An appropriate method is chosen that reliably simulates the process within a reasonable time ${ }^{75,76}$.

The basis for structural prediction is finding the structure with lowest energy. The hallmark for macromolecules with low energy is the lack of polar residues facing a non-polar environment or vice versa, a nearly void-free protein structure and intramolecular hydrogen bond formation. The method, therefore, must to calculate hydrophobic effects, van der Waals interactions, electrostatic interactions, and the free energy of creating large proteins and stripping water to create hydrogen bonds ${ }^{77}$.

Rosetta modeling and molecular dynamics were performed by the Erik Lindahl group at the Stockholm University and Royal Institute of Technology in Stockholm. 


\section{Results and discussion}

This thesis focuses on the conformational changes that occur in the $K_{v}$ channel during gating and how these changes are connected to channel opening, closing, and inactivation. The following chapter contains a summary of the results and discussions from the three papers.

\section{Voltage-sensor movement during channel gating (Paper I and II)}

In the early 21-st century, a lively debate regarding the movements occurring within the VSD during gating ensued. Three different models were proposed: The first model, known as the paddle model, described a synchronized movement of the outer part of S3 together with S4 as a single unit as S4 moved during gating. The voltage-sensor paddle was considered to move more freely in the membrane with a displacement of approximately 15-20 A. The second model, known as the helical screw model, assumed that the motion of S4 was independent that of S3. S4 was considered to move approximately $10 \AA$ through the membrane with a rotation along its length axis. The third model, known as the helical-tilt or rocking-banana model, suggested only a minor S4 movement through the membrane. Instead, S4 was considered to tilt during gating.

\section{$\mathrm{Cd}^{2+}$ interactions suggest a sliding motion of S4 along S3}

We investigated S4 movement by searching for interactions between residues in S3 and S4 at various points during gating in order to study the movement of S4 during gating. The interactions found were used to create snapshots of S4 at various points during its gating motion. 325 and 326 in S3 have previously been shown to be close to gating charges R1 (R362), R2 (R365) and R3 (R368) in the open state ${ }^{78}$. We, therefore, probed for interactions between 325 or 326 in S3 and residues 355 to 372 in S4. We also included 327 in S3 in our screen since there is the possibility of a rotation of S3 during gating (Fig. 10).

Interactions were probed by pair-wise mutating one residue in S3 and one in S4 and investigating any $\mathrm{Cd}^{2+}$-induced effects on gating kinetics. An interaction was considered to occur in the closed state if $\mathrm{Cd}^{2+}$ caused a positive $\mathrm{G}(\mathrm{V})$ shift or a slowing of the opening kinetics. An interaction was considered to occur in the open state if $\mathrm{Cd}^{2+}$ caused a negative $\mathrm{G}(\mathrm{V})$ shift or a slowing of opening kinetics (Fig. 9). 


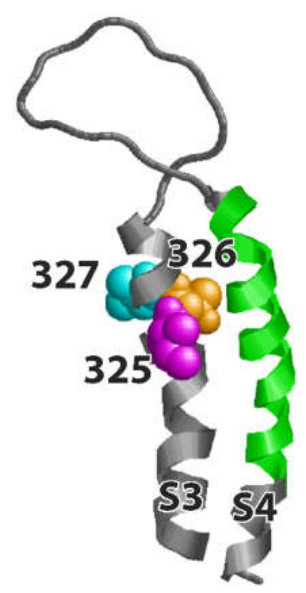

Figure 10. Residues screened for interactions during gating in the $\mathrm{K}_{\mathrm{v}} \mathbf{1 . 2} / \mathbf{2 . 1}$ chimera $^{14}$. Interactions between 325 (magenta), 326 (orange) and 327 (cyan) in S3 and the stretch of residues in S4 (green) were investigated.

Of the 45 mutations investigated, 22 interactions were found at various points during gating. In the following section, I will show examples of two mutants that form $\mathrm{Cd}^{2+}$ bridges, one forming a bridge in the closed state and one in the open state.

In the $\mathrm{I325C} / \mathrm{L} 358 \mathrm{C}$ mutant, $\mathrm{Cd}^{2+}$ reduced the opening rate by a factor of 590 (Fig. 11A) and induced a shift $G(V)$ of $30 \pm 4 \mathrm{mV}$ (Fig. 11B). This is expected for an interaction in the closed state. The $\mathrm{Cd}^{2+}$ bridge formed between $\mathrm{I325C}$ and $\mathrm{L} 358 \mathrm{C}$ must be broken in order for $\mathrm{S} 4$ to travers outward and open the channel. The energy required to open the channel therefore increases, resulting in a $G(V)$ shift in the positive direction and a slowed opening.

In the T326C/R368C mutant, $\mathrm{Cd}^{2+}$ reduced the closing rate by a factor $>100$ (Fig. 11C) and induced a shift of the $G(V)$ of $-61 \pm 2 \mathrm{mV}$ (Fig. 11D). This is expected for an interaction in the closed state. The $\mathrm{Cd}^{2+}$ bridge formed between $\mathrm{I326C}$ and $\mathrm{R} 368 \mathrm{C}$ must be broken in order for $\mathrm{S} 4$ to return to its down position and close the channel. The energy required to close the channel therefore increases, resulting in a $G(V)$ shift in the negative direction and a slowed closing.

We found a total of six residues in S4 that interact with 1325C, one in the open state and five in the closed state or states. Five residues in $\mathrm{S} 4$ were found to interact with T326C, two in the open state and three in the closed state. One residue in S4 was found to interact with L327C in the open state (Fig. 12). 

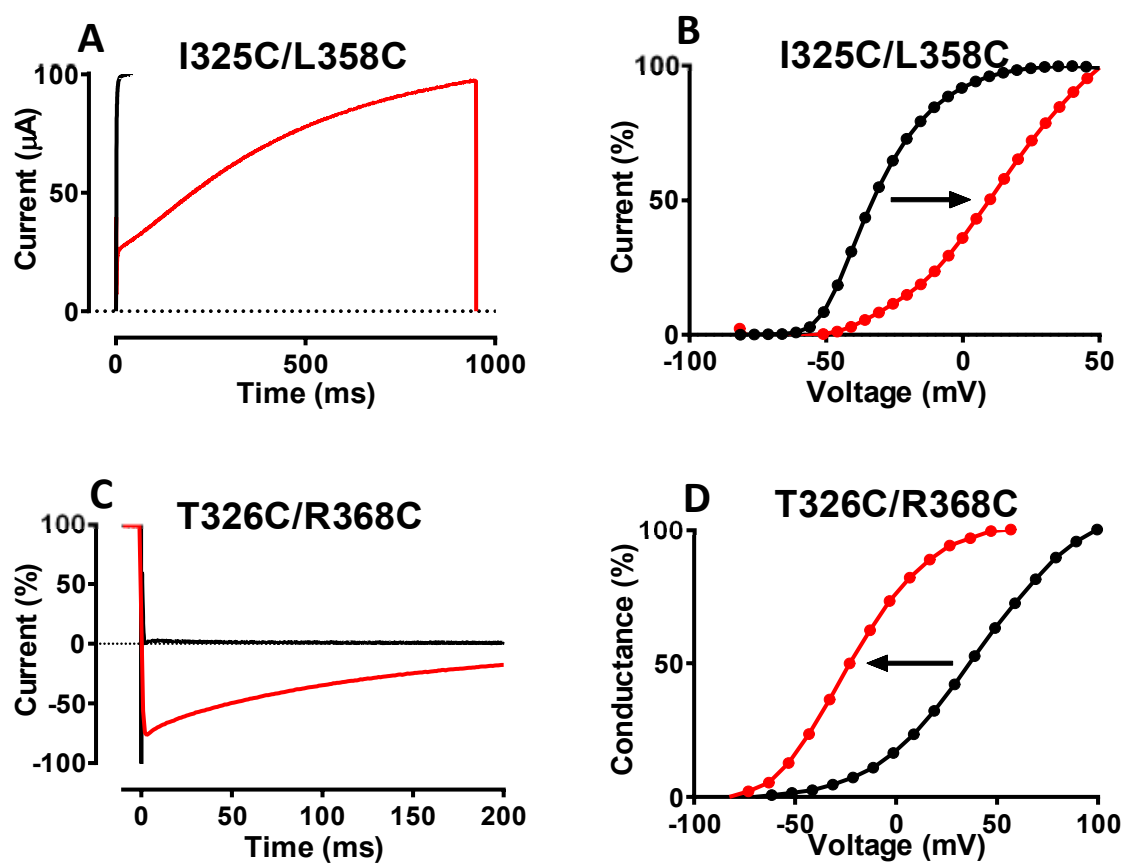

Figure 11. Effect of $\mathrm{Cd}^{2+}$ bridge formation in the closed and open states. $(A) \mathrm{Cd}^{2+}$ reduced the opening rate by a factor by 590 in the $1325 \mathrm{C} / \mathrm{L} 358 \mathrm{C}$ mutant. (B) $\mathrm{Cd}^{2+}$ caused a right shift in the voltage dependence of $30 \pm 4 \mathrm{mV}$ in the $\mathrm{I325C} / \mathrm{L} 358 \mathrm{C}$ mutant. (C) $\mathrm{Cd}^{2+}$ reduced the closing rate by a factor of $>100$ in the T326C/R368C mutant. (D) $\mathrm{Cd}^{2+}$ caused a left shift of the voltage dependence of $61 \pm \mathrm{mV}$ in the T326C/R368C mutant. Recordings were performed with (red) or without $10 \mu \mathrm{M} \mathrm{Cd}{ }^{2+}$ (black).
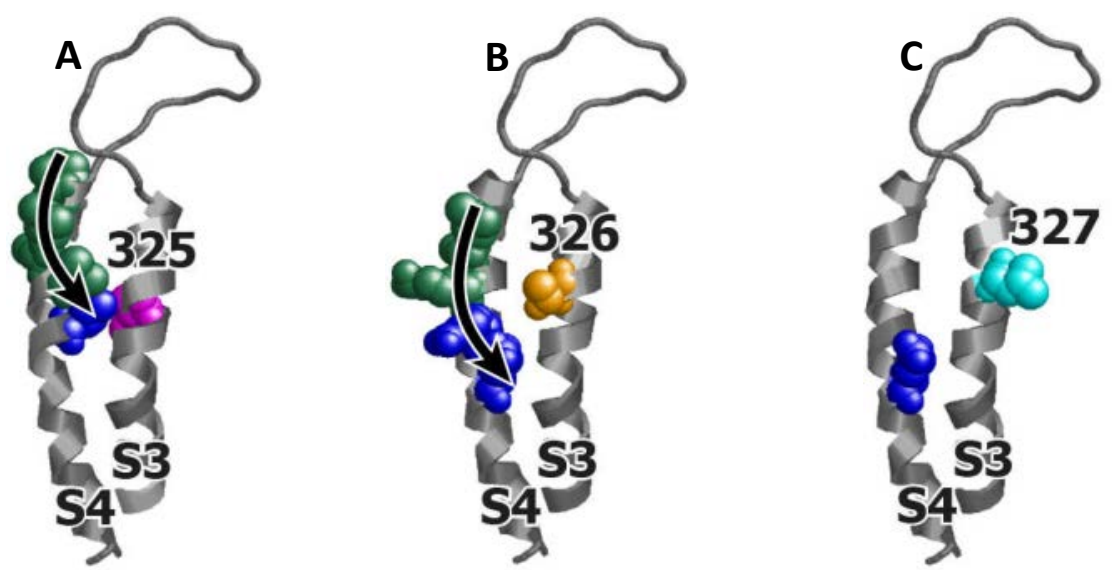

Figure 12. Summary of interactions. (A) Six residues in S4 interacted with 325. (B) Five residues in S4 interacted with 326. (C) One residue in S4 interacted with 327. For all panels, residues that formed an interaction in the closed state are shown in dark green, and residues that formed an interaction in the open state are shown in blue. Residue 325 is shown in magenta, 326 in orange, and 327 in cyan. 
The residues in S4 found to interact with 325 or 326 are located one on top of each other on one side of S4 (Fig. 12), suggesting that residues 325 and 326 are close to different residues in $\mathrm{S} 4$ at different time points during gating. This is consistent with the helical screw model but not the other models.

\section{Molecular models of the VSD in different states}

Atomic resolution computer models for each state were built based on the experimental data from Paper I, using Rosetta modeling. A homology model of the VSD was generated by aligning the Shaker sequence to the crystal structure of the Kv1.2/Kv2.1 chimera. The homology model was used to create models for each state using data from the $\mathrm{Cd}^{2+}$ bridge experiments as constraints. The models were refined using molecular dynamics. The simulations were performed by the Erik Lindahl group at the Stockholm University and Royal Institute of Technology in Stockholm.

The computer simulations showed that S4 slides at least $12 \AA$ along S3 as it moves from the open (O) state to the deep closed (C3) state. A part of S4 adopted a $3_{10}$ helical structure fixed in space relative to F290 during the sliding motion. Arginines in S4 above F290 formed salt bridges with E283, and Arginines below F290 formed salt bridges with E293. The salt bridges stabilized S4 between residues E283 and E293, resulting in the 310 helical structure (Fig. 13).
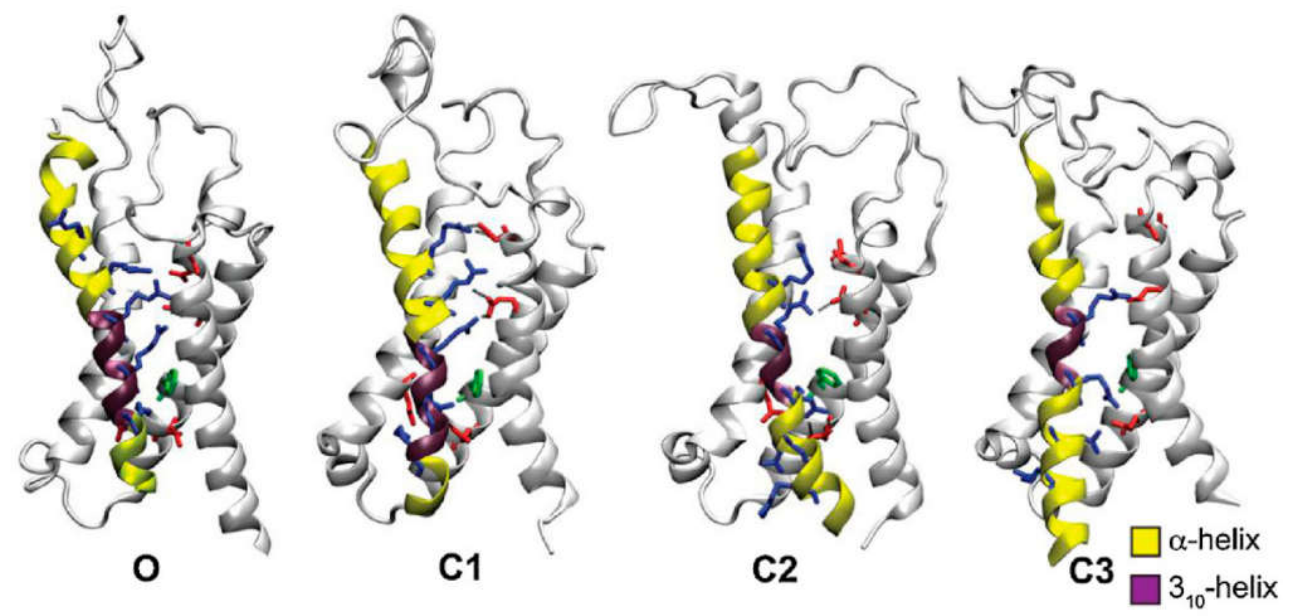

Figure 13. Molecular models of the open (O) state through closed (C3) state. S4 adopted an $\alpha-$ helical conformation (yellow) with a 310 -helical structure (purple) fixed in space relative to F290 (green) during gating. The positive arginines in $\mathrm{S4}$ (blue sticks) formed salt bridges with negatively charged residues in S1-S3 (red sticks) as S4 moved through the VSD.

The generated open-state model was structurally close to the determined atomic structure of a $\mathrm{K}$ channel ${ }^{14}$. The subsequent closed states are compatible with some 
experiments ${ }^{79,80}$ and they are similar to previously suggested closed states ${ }^{81,82}$. The model suggests a sliding motion of $\mathrm{S} 4$ that is only compatible with the sliding helix model. The numerous interactions found when S4 is in the down position suggest some flexibility in the closed state. Two additional interactions in the open state were found after the model was generated. The effects seen in the T326C/R368C mutant were the largest of any mutant investigated. The residues are found close to each other in our generated open state model suggesting that the model closely represents the open state. $\mathrm{A} \mathrm{Cd}^{2+}$ bridge between the residues would require $\mathrm{S} 4$ to reach its most outward position and that the two residues point towards each other. $\mathrm{A} \mathrm{Cd}^{2+}$ bridge in this position would prevent any $\mathrm{S} 4$ movement, causing the large $\mathrm{Cd}^{2+}$ induced effects. An interaction was also found between L327C and R368C, but the effects were smaller and induced slower than that of T326C/R368C. Our interpretation is that while this interaction occurs in the open state it is not in a common open state.

\section{VSDs interact with each other (Paper II)}

It has been shown that each S4 moves in two to three discrete steps before the channel opens ${ }^{38,43,83,84}$. It has been suggested that each S4 moves independently of the others from a closed down position to a primed up-position and that this is followed by a concerted channel opening step $38,43,85,86$. It is not clear if the final step involves the movement of S4 or if it follows after the last S4 transition and involves changes in parts of the channel other than S4. In the following section we will discuss the cooperativity between the subunits in the final S4 transition.

\section{Cooperativity between subunits during channel closure}

If there is positive cooperativity in the final $\$ 4$ movement, the downward movement of one S4 will promotes the downward movement of neighboring S4s. The opposite is also true, where S4s in the up-position prevent the downward movement of a single S4. Trapping a S4 in an up-position using a $\mathrm{Cd}^{2+}$ bridge not only prevent the downward motion of the trapped S4, it will also affect neighboring S4s. If there is no cooperativity between subunits, each $\$ 4$ will move independently of the others. Trapping a S4 will prevent the downward motion of that S4 but will leave the movement of the neighboring subunits unaffected.

To explore cooperativity, the T326C/R368C double mutation was introduced into zero, two, or all four VSDs of the channel. This was achieved by the creation of dimeric concatemers containing zero, one or two mutations. The R368C mutation was introduced in the subunit that did not carry the double mutation in order to make the four S4s of the channels structurally identical. If there is no cooperativity 
between subunits, the closing rate of the channel with two T326C/R368C and two $\mathrm{R} 368 \mathrm{C}$ will be dictated by the fast closing R368C containing subunits. The closing rate of the channel will be the sum of the closing rates for all S4s of the channel according to Eq. 2. If there is cooperativity, the closing rate of the individual S4 will be affected by its neighbors and can be calculated according to Eq. 3 .

Closing rate was measured by pulsing to $+100 \mathrm{mV}$ for $100 \mathrm{~ms}$ and then to $-100 \mathrm{mV}$. An exponential curve was fitted to the tail current. The closing rate of the concatemer that only contained R368C mutations (R368C-R368C) was calculated to 0.05-0.5 ms, and the closing rate of the mutant that only contained T326C/R368C mutations (T326C/R368C-T326C/R368C) was $55 \pm 5 \mathrm{~ms}(n=3)$ in $10 \mu \mathrm{M} \mathrm{Cd}^{2+}$ (Fig. 14A).
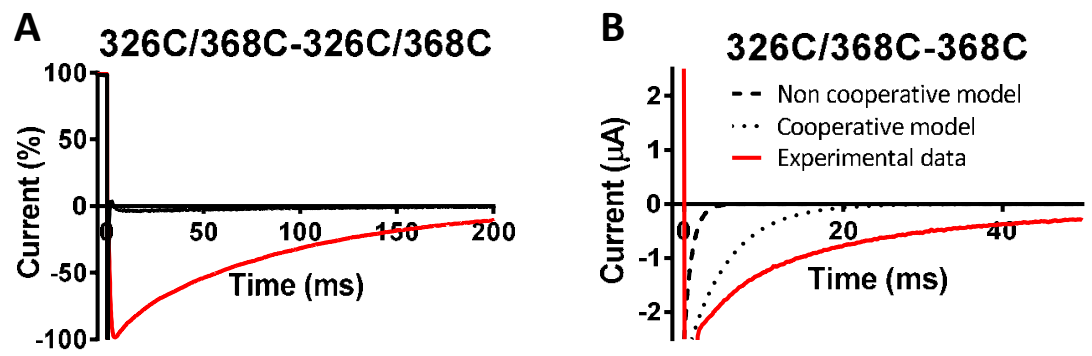

Figure 14. Closing of the T326C/R368C- or R368C-containing concatemer. (A) $\mathrm{Cd}^{2+}$ reduced the

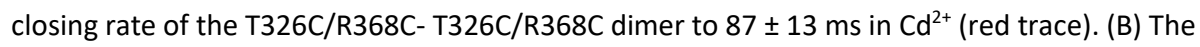
closing rate of the T326C/R368C- R368C dimer was $12.2 \pm 1.7$ in $\mathrm{Cd}^{2+}$ (red trace) which fits better with the predicted closing rate of $5.2 \mathrm{~ms}$ of the cooperative model (dotted line) than the $1.0 \mathrm{~ms}$ of the non-cooperative model (dashed line).

The closing rate for the dimer that contained one R368C and one T326C/R368C mutated subunit can be expected to be $0.1-1.0 \mathrm{~ms}$ if there is no cooperativity (Eq. 2) and 1.7-5.2 $\mathrm{ms}$ if there is cooperativity (Eq. 3; Fig. 14B). The closing rates for the T326C/R368C-R368C and R368C-T326C/R368C channels were $12.2 \pm 1.7$ and $15.5 \pm$ $1.1 \mathrm{~ms}$ respectively, which strongly supports the cooperative model. The $\mathrm{Cd}^{2+}$ bridge formed between T326C and R368C only forms when S4 has reached its most outward position and can, therefore, only be broken by the downward movement of S4. This suggests that the cooperative step involves the final S4 transition.

\section{VSDs interact via the internal gate}

We have clearly shown that there is cooperativity between the subunits in the final S4 transition. How can so distant molecular structures as the S4s affect each other? The communication between the subunits is most likely transmitted via the pore domain. In order to identify the path of cooperativity, we searched for mutants that alter cooperativity. Disruption of cooperativity is expected to cause a reduction in 
voltage dependence, or the slope of the $G(V)$ curve, because a large gating charge is split in several smaller one.

For this reason, we investigated mutations in residues R394, G406, W454, 1457, V476, and $Y 485$ that had been found to have a reduced $G(V)$ slope without any major shifts in the midpoint of the $G(V)$ curve $^{87,88}$. Residues $W 454$ and 1457 are located at the extracellular end of S6, G406 in the middle of S5, and R394, V476, and Y485 are located close to the gate in S5 and S6 (Fig. 15A). A disruption of cooperativity will result in a decrease in gating charge movement, or valence, during channel opening and closing. The total valence was calculated as the sum of the effective gating charge for voltage dependence during opening $\left(z_{\alpha}\right)$ and closing $\left(z_{\beta}\right)$ (see Methods). Of the six investigated mutants, only mutations to residues $\mathrm{V} 476$ and $\mathrm{Y} 485$ caused a reduction in the total valence (Fig. 15B). V476 and Y485 are close to each other in the internal gate.

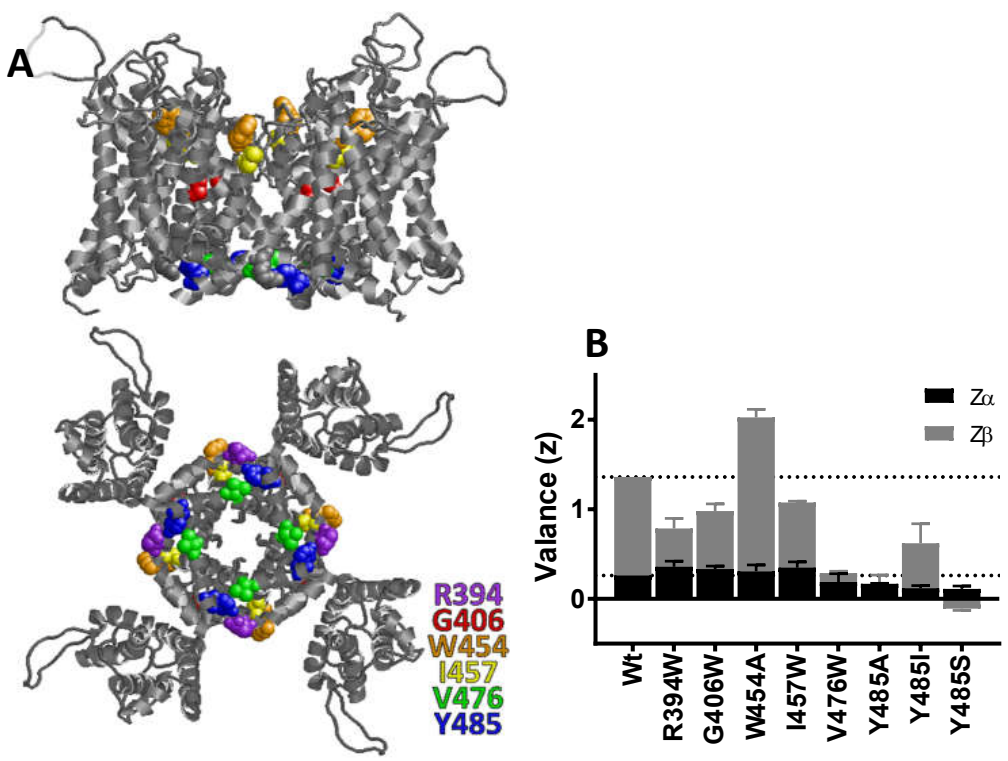

Figure 15. Residues screened for their role in cooperativity. (A) Molecular structure of a Shaker Kv channel seen from the side (top) and from the intracellular side (bottom). Residues included in the screen are highlighted. (B) Voltage dependences for opening and closing kinetics for the mutants are shown as valences.

The role of V476 and Y485 in cooperativity can be studied in the concatemer. We therefore introduced V476W or Y485A into both subunits of the concatemers containing zero, one or two T326C/R368C mutations. Only the Y485A mutation expressed in the concatemers. $\mathrm{Cd}^{2+}$ slowed down the closing rate by a factor of only 8 instead of a factor of $<110$ as for the WT channel. This suggests that residue Y485 
play a role in transmitting the cooperativity between two distant voltage sensors. A tentative mechanism is described in Fig. 16. The S4s move endependent of each other up to a primed state. From the primed state all four S4s move in a concerted step together with gate opening to an open state. Downward movement of the S4s is prevented by the open gates.

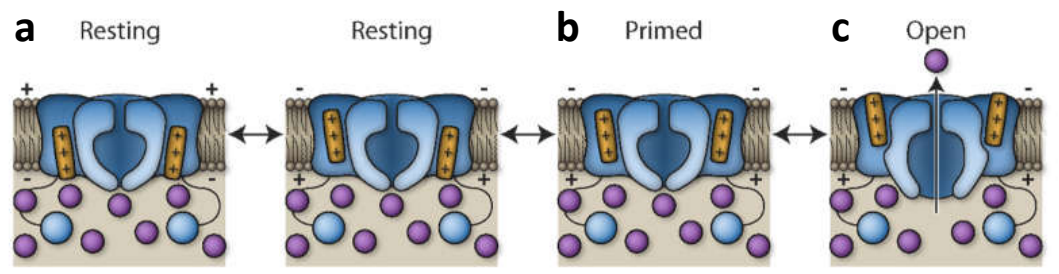

Figure 16. Gating of the $K_{v}$ channel. The channel is closed at hyperpolarized voltages with its voltage sensors in a down-position (a). Upon depolarization, the voltage sensors independently transvers several intermediate steps to reach a primed up-position (b). S4 performs a final cooperative transition that opens the internal gate (c).

\section{Voltage sensor-to-pore communication during C-type inactivation (Paper III)}

$\mathrm{K}_{v}$ channels have two mechanisms of inactivation upon activation. The fast, or $\mathrm{N}$ type, inactivation occurs on the millisecond time scale and is caused by a physical blocking of the pore by an $\mathrm{N}$-terminal ball. Fast inactivation can be eliminated by the removal of the $\mathrm{N}$-terminal ball, thereby revealing the slow, or $\mathrm{C}$-type, inactivation. Slow inactivation is characterized by structural rearrangements that occur in the selectivity filter leading to ceased ion conductivity.

Prolonged depolarization not only causes structural rearrangements in the pore of the channel but it also affects the VSDs. The voltage dependence of the current generated by the voltage sensors during gating, also known as the gating current, shifts during prolonged depolarization (Fig. 5). It still remains unknown how changes in the VSD affect the pore and how the reconfiguration of the pore affect voltagesensor movement.

\section{Interactions between the pore and the VSD affect C-type inactivation} It has been shown that the glutamate (E418) at the periphery of the pore has an important role in slow inactivation ${ }^{50,89}$. It has also been suggested that F416, which is a neighbor to glutamate E418, may play a role in the VSD-to-pore domain communication $^{90}$. For this reason, we explored the role of F416 in the communication between the VSD and the pore during C-type inactivation and the structural rearrangements that affect the time course of C-type inactivation. 
By substituting the large uncharged phenylalanine at position $\mathrm{F} 416$ for the shorter and negatively charged aspartate (F416D), C-type inactivation was accelerated by a factor of 4 (Fig. 17A). There was no acceleration in the rate of inactivation if the residue was substituted to the longer and negatively charged glutamate nor to the shorter and uncharged alanine. The residue must be both short and negatively charged to affect the rate of C-type inactivation.

F416 is close to the gating charges in S4. It is possible that the introduction of the negatively charged aspartate at position F416 was attracted to the gating charges, leading to a distortion at the top of $\mathrm{S} 5$ and in the selectivity filter. The decrease in stability in the selectivity filter, in turn, accelerated C-type inactivation. This can be tested by forming a $\mathrm{Cd}^{2+}$ bridge between $\mathrm{F} 416$ and the arginines in $\mathrm{S} 4$, by mutating them to cysteines. The introduction of a $\mathrm{Cd}^{2+}$ bridge between residue $\mathrm{R} 365 \mathrm{C}$ and F416C caused an acceleration in C-type inactivation similar to the F416D mutant, indicating that an interaction between residues R365 and F416 causes an accelerated C-type inactivation (Fig. 17B). 

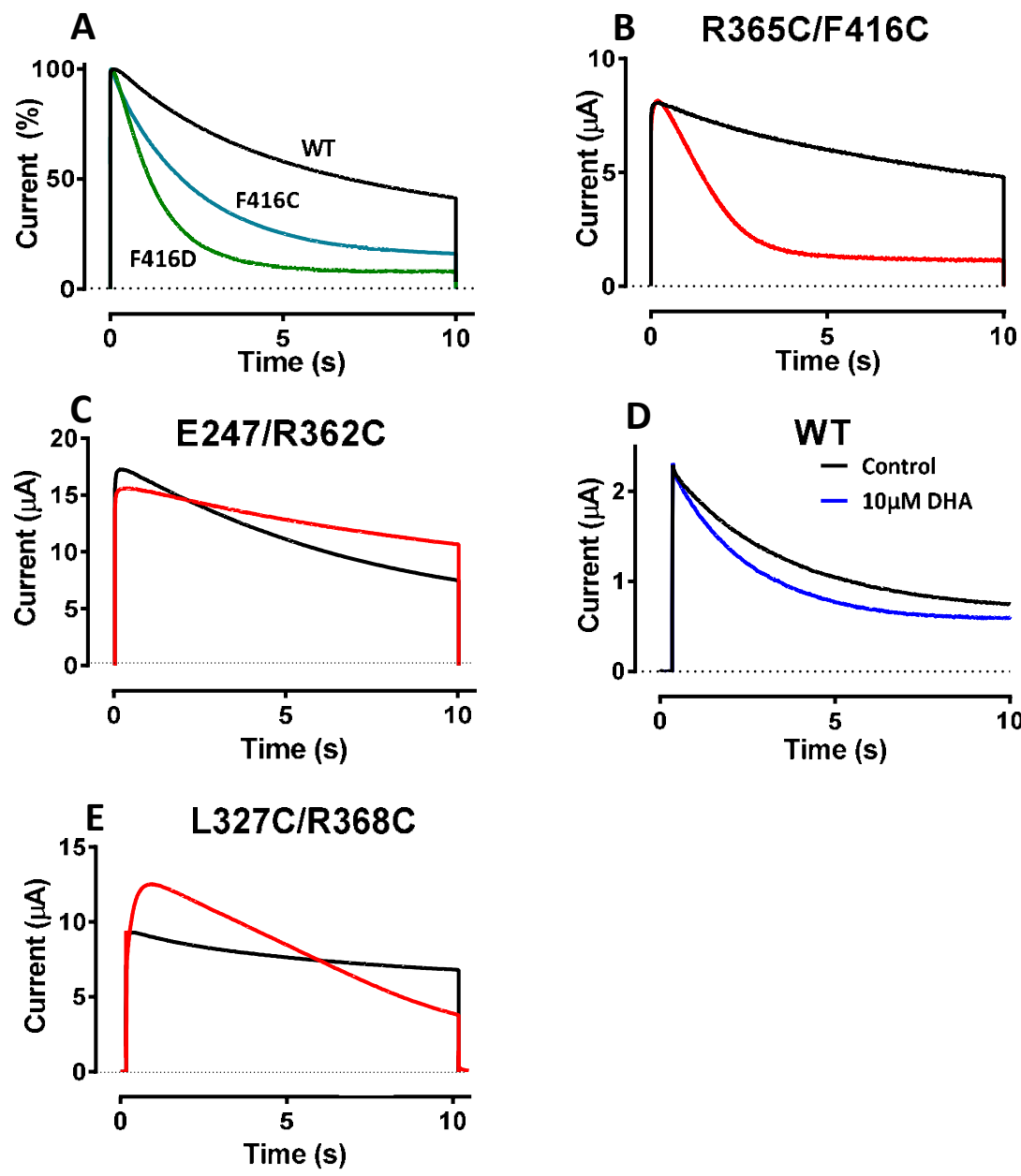

Figure 17. Changes in the pore domain/VSD interface and within the VSD altered C-type inactivation. (A) Mutating residue $\mathrm{F} 416$ to a cysteine or serine accelerates $\mathrm{C}$-type inactivation. (B) $\mathrm{Cd}^{2+}$ accelerates C-type inactivation in the R365C/F416C mutant. (C) $\mathrm{Cd}^{2+}$ decelerates C-type inactivation in the E247/R362. (D) $70 \mu \mathrm{M}$ DHA accelerates inactivation in the WT channel. (E) $\mathrm{Cd}^{2+}$ accelerates C-type inactivation in the L327C/R365C mutant. In all panels, control experiments are shown in black and experiments in $10 \mu \mathrm{M} \mathrm{Cd}^{2+}$ are shown in red.

C-type inactivation was not only affected by alterations in the interface between the VSD and the pore. C-type inactivation can also be affected by introducing alterations in the VSD alone. $\mathrm{A} \mathrm{Cd}^{2+}$ bridge created between a cysteine introduced at position 362 (R362C) in S4 and the endogenous glutamate 247 (E247C), in the outer part of $\mathrm{S} 1$, caused a deceleration in C-type inactivation (Fig. 17C). The formation of the $\mathrm{Cd}^{2+}$ bridge between $\mathrm{E} 247 \mathrm{C}$ and $\mathrm{R} 362 \mathrm{C}$ probably prevents the clockwise rotation of S4 during its last channel-opening transition. 
If C-type inactivation can be decelerated by preventing the clockwise rotation of S4, it should be accelerated by promoting a clockwise rotation. By adding polyunsaturated fatty acids (PUFAs), which are known to induce a clockwise rotation of $\mathrm{S}^{91,92}$, the inactivation time constant can be accelerated by $34 \%$ (Fig. 17D). This supports the hypothesis that the rotation, or possibly tilting, of S4 modifies the speed of C-type inactivation. The acceleration or deceleration of C-type inactivation is dependent on the direction of the rotation.

The formation of a $\mathrm{Cd}^{2+}$ bridge in the L327C/R368C mutant reduced the steady-state current from $63 \%$ to $12 \%$ with only a slight acceleration to the inactivation rate (Fig. $17 \mathrm{E}) . \mathrm{Cd}^{2+}$ also induces a shift in the voltage dependence of $-38 \pm 5 \mathrm{mV}$ seen as an increase in current at $+80 \mathrm{mV}$ (Fig. 17E). The increase in current is induced slowly even at positive voltages where most of the channels are expected to be open (216 \pm $7 \mathrm{~ms}$ at $+80 \mathrm{mV} ; n=4)$. This suggests that the $\mathrm{Cd}^{2+}$ bridge cannot form when the S4 reaches its up-position. Instead, a large conformational change in the open state is required for the bridge to form. In this state, the bridge stabilizes the inactivated conformation, preventing the channel from recovering.

The data suggests that pulling F416 towards the VSD promotes C-type inactivation. To test this, steered molecular dynamics was used to pull F416 away from the pore. The centrifugal force applied to F416 caused an outward motion of S5, leading to a perturbation of the geometry of the backbone of the selectivity filter. This caused the removal of $\mathrm{K}^{+}$from the binding sites within the selectivity filter, probably rendering the channel nonconductive (Fig. 18). The expanded outer part of the selectivity filter allowed for the entry of $\mathrm{Na}^{+}$and water molecules as $\mathrm{K}^{+}$exited the filter. The simulations was performed by the Erik Lindahl group at the Stockholm University and Royal Institute of Technology in Stockholm.

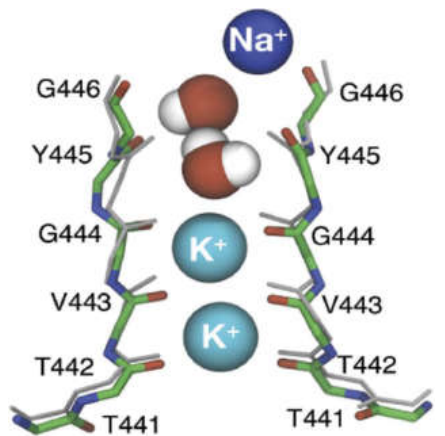

Figure 18. Molecular model of the selectivity filter. Computer-generated model of the inactivated filter where water molecules and $\mathrm{Na}+$ ions interact with carbonyls (red sticks) in positions 445 and 446. Overlay with initial molecular structure (gray). 


\section{C-type inactivation causes changes to the VSD}

We have shown that alterations in the VSD affect C-type inactivation. The question is if the reconfiguration of the selectivity filter during C-type inactivation reach the VSD. To test this, the movement of the voltage sensors was studied in the resting and the inactivated channel by measuring gating-charge movement. Gating current generated by the movement of the gating charges in the voltage sensors can be measured when ion conductivity is eliminated with the W434F mutation ${ }^{57}$.

The gating charge movement is dependent on holding voltage. Holding the membrane voltage at depolarized voltages causes structural rearrangements in the channel, obstructing the return of the voltage sensor. The voltage sensor, therefore, requires more energy, and a more negative membrane voltage to return to the resting position. For this reason, the gating charge movement occurs at more negative voltages if the channel is held at depolarized voltages than if the channel is held at hyperpolarized voltages (Fig. 19A). This phenomenon is known as mode-shift.

Since mutations to F416 affect the C-type inactivation (Fig. 17A), we wanted to investigate if the mutation also affect the mode-shift. Mutations to F416 were combined with the $\mathrm{W} 434 \mathrm{~F}$ mutation, and gating currents were recorded. The W434F/F416D did not generate any gating currents, the W434F/416C was, therefore, used instead.
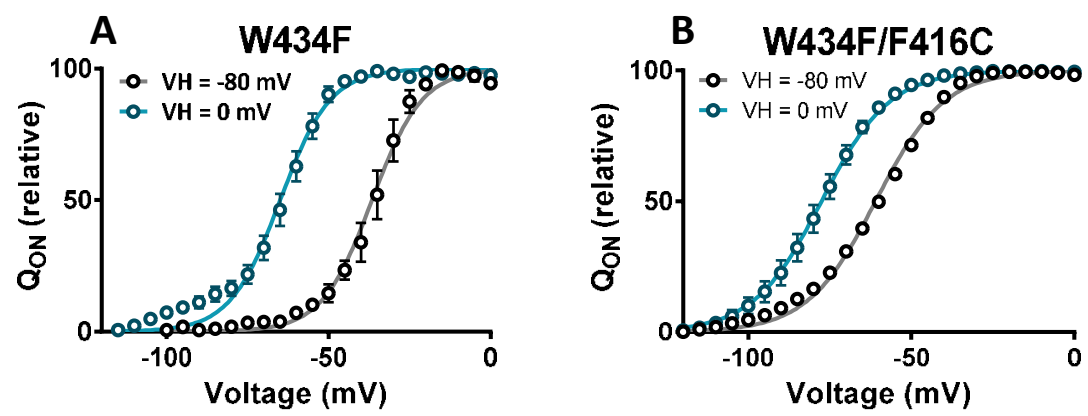

Figure 19. Gating charge movement at different holding voltages. (A) The mode-shift is $-28.3 \mathrm{mV}$ in the W434F mutant. (B) The mode-shift is $-19.2 \mathrm{mV}$ in the W434F/F416C mutant.

The $\mathrm{Q}(\mathrm{V})$ shift for the W434F/F416C was $-19.2 \mathrm{mV}$, which is much smaller than the shift of $-28.3 \mathrm{mV}$ for the W434F mutant (Fig. 19A,B). This shows that residue F416, located on the extracellular end of $\mathrm{S} 5$, modifies the gating charge movement.

The present study found communication between the VSD and the pore. The rotation of the voltage sensor can either accelerate or decelerate the rate of C-type inactivation, depending on the direction of the rotation. The centrifugal movement 
of the extracellular end of S5 causes both a dilatation of the pore leading to an inactivated channel, as well as an alteration in voltage-sensor movements. The reconfiguration occurring in the selectivity filter during slow inactivation also affects voltage-sensor movement, causing the voltage sensor to deactivate through an energetically different pathway.

\section{Channel gating}

The results presented in this thesis and by others provide a picture of molecular motions that take place within the channel during gating. The four S4s are located on the intracellular side of the VSD at hyperpolarized membrane voltages (Fig. 20a). The S4s move independently of each other from a down-position to a primed up-position upon depolarization (Fig. 20b). This is followed by a channel-opening cooperative transition that involves all S4s (Fig. 20c).

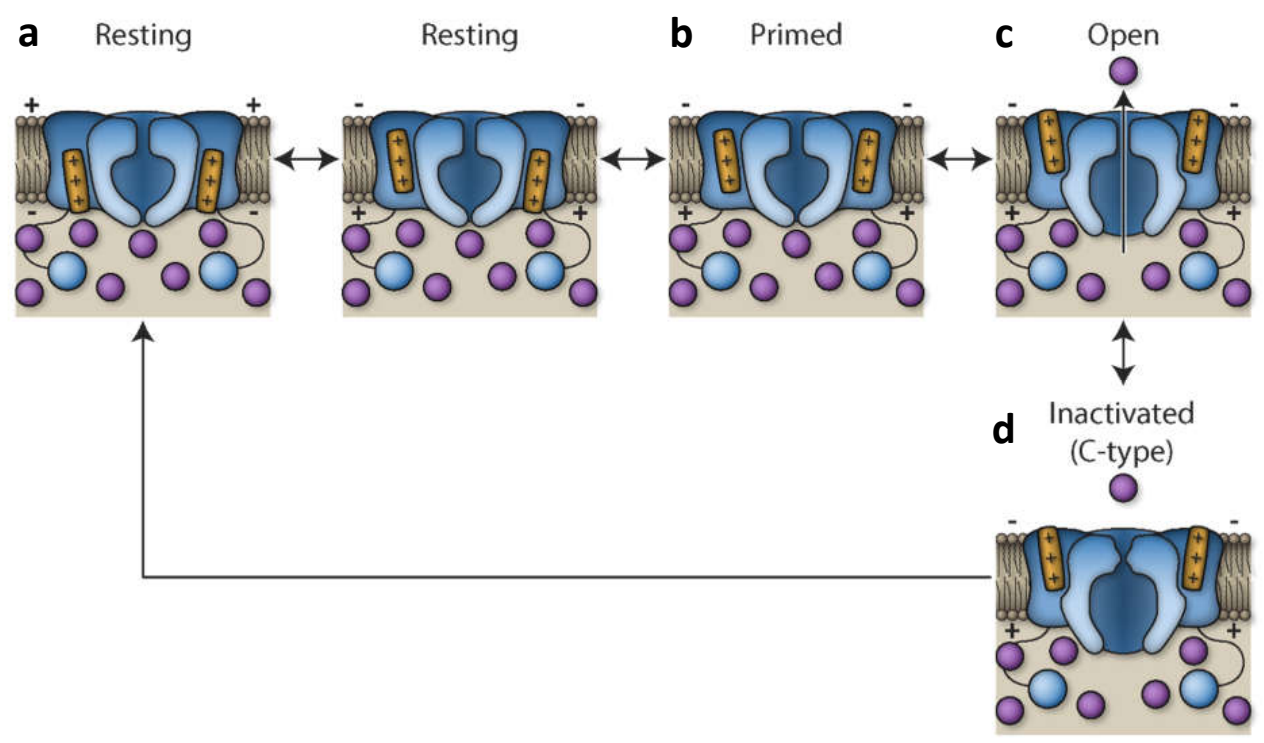

Figure 20. Gating of the $K_{v}$ channel. The channel is closed at hyperpolarized voltages, with its voltage sensors in a down-position (a). Upon depolarization, the voltage sensors independently transvers several intermediate steps to reach a primed up-position (b). The internal gate opens after a final cooperative $\mathrm{S} 4$ transition (c). The $\mathrm{S} 4 \mathrm{~s}$ in an up-position induce $\mathrm{C}$-type inactivation, causing a reconfiguration of the selectivity filter leading to ceased ion conductivity (d). Inactivation in turn influences $\mathrm{S} 4$ movement. $\mathrm{K}^{+}$is shown as purple spheres and $\mathrm{S} 4$ as yellow rods.

The S4 in an up-position interacts with the selectivity filter via residues on the extracellular side of the pore, decreasing the stability of the filter and thereby inducing C-type inactivation (Fig. 20d). The inactivated selectivity filter also induces changes in the VSD, making it harder for S4 to return to its down-position. 


\section{Concluding remarks}

Voltage-gated potassium channels can sense the membrane voltage with remarkable precision and open and close its gate with incredible speed. This is performed with synchrony between the segments and subunits of the channel. The focus of this thesis was to investigate and explain structural changes occurring in the channel during gating and the communication between the subunits.

The experiments presented in this thesis, and by other groups, show that $\mathrm{S} 4$ moves a considerable distance relative S3 during gating, as it moves from a down-position to an up-position. This motion is not compatible with a model including a S3b-S4 paddle or a helical-tilt model with minor translational movement.

We have also presented direct evidence supporting cooperativity between the subunits in the final S4 transition.

It is known that the VSD communicates with a pore via its linker to the gate, and it is also known that the gate communicates with the selectivity filter ${ }^{21,63,71}$. To our knowledge, there is no previous evidence of communication between the VSD and the pore via the interface between them. In this thesis, we have shown reciprocal communication between the selectivity filter that occurs via the interface between the VSD and the pore. Changes in the VSD are transferred to the pore where they lead to the C-type inactivation of the filter. The opposite is also true; reconfiguration in the selectivity filter changes the energetic landscape of the VSD, causing a shift in the voltage-dependent movement of the voltage sensor.

The mechanisms mentioned above occur may only be shared between different types of channels if the involved part of the channel is conserved. The selectivity filter, for example, only involves five amino acids per subunit, and these residues are relatively well conserved between different potassium channels. The mechanism and importance of the reconfiguration of the selectivity filter may, therefore, be shared among many different types of channels. The communication between subunits and domains, on the other hand, involve many large parts of the channel. These parts may have different degrees of importance and different roles in different channels due to the varying function of the segments. The mechanism of opening the gate, the importance of internal $\mathrm{pH}$ or calcium levels, and the effect of temperature and pressure are different in different channels. Some channels rely on large intracellular domains or auxiliary subunits for their correct function. Since the importance and function of the segments in gating varies between channels, it is also likely that the 
communication between these segments varies, which different studies have confirmed $22-28,58,60,63,71$.

Channels share aspects of gating, such as voltage-sensor movement, but they differ in other aspects, such as the mechanism of opening the gate. Channel function can be modified by binding drugs that have been designed to target specific structures of the channel. The function of a subgroup of channels can be altered by targeting a structure that is specific to that subgroup, thereby minimizing binding to other channels and reducing side effects. The behavior of the channel can also be modulated by affecting different parts of the channel. Ion conductivity can be eliminated by blocking the pore, voltage sensitivity can be changed by targeting the voltage sensor, and opening and closing rates can be affected by targeting the VSD. The research presented in this thesis, and by others, provides a foundation for designing drugs that target specific channels or aspects of channel gating. 


\section{Acknowledgments}

This thesis would not have been possible without the support of and motivation by many people. I would specially like to thank:

My main supervisor Fredrik Elinder for your always enthusiastic scientific discussion and for allowing me to test my own ideas even though the chances of success were slim. Your scientific guidance and impeccable memory of decades old articles have been invaluable.

My co-supervisor David Engblom for good scientific discussions and help with molecular biology as well as discussions regarding the best way to drill a hole through the earth.

The wonderful people in the Elinder group: Sara Liin for introducing me to the lab and teaching me how to do electrophysiological recordings. You always bring a smile and exuberant energy to the lab. It is sad that we won't share the same setup any more. Ulrike Henrion for working with the endless stream of mutants and the detective work of elucidating what's in the mislabeled tubes. Johan Brask for all technical support and help with microbiology. It has been a blast trying to fix setups, micromanipulators, and microscopes together, where we have taken turns trying to fix what's broken while the other has tried to "help" by making the most useless suggestions and comments. Nina Ottosson for your constant support and encouragement. You have helped me with countless small and large things, and I know I can always count on you. Luca Conti for many hours of hard work in the lab and countless hours of scientific discussions as well as discussions regarding Italian cuisine, travels, and other things that make life enjoyable. Malin Silverå Ejneby for well-contemplated thoughts often regarding systems and simulation, and also for being great company on the trip back from the states. Ulrika Englund for always having a high spirit and for sharing your crazy night dreams, making the hitchhiker's guide to the galaxy seem normal. Urban Karlsson for sharing you extensive knowledge of neurons and electrophysiology and your well timed and funny remarks. Andreas Nolting for your always helping attitude. Johan Larsson for an always positive attitude, help in the lab, and a fun tree hugging trip in the states. Olle Rönnelid for scientific discussions, a lot of laughter, and help with the Zink project (data not shown). Sajjad Salari for bringing new ideas and keeping our spirits high. Erin Nelson and Fredrik Turesson for help recording our endless supply of mutants.

The people in the Erik Lindahl group for doing the computer modeling. 
The people currently or previously at floor 11: Anders Blomqvist, Unn Kugelberg, Kiseko Shionoya, Anna Eskilsson, Johan Ruud, Ana-Maria Vasilache, Takashi Matsuwaki, Simin Mohseni, Ayman Osman, Daniel Björk Wilhelms, Anna Klawonn, Michael Fritz, Elahe Mirrasekhian, Anna Nilsson, Björn Granseth, Gonzalo Sanchez, Erik Johansson, Anders Fridberger, Pierre Hakizimana, Batu Keceli, and Sonal Prasad for creating a friendly atmosphere filled with scientific discussions as well as many jokes and a lot of laughter. A special thanks to Sofie Sundberg and Sarah Lindström for sharing office space, ideas, struggles, and laughter. Also, a special thanks to Maarit Jarola for help in the lab, without you my concatemers would have never been made.

Thanks to the people at the core facility for sequencing the roughly 400 samples necessary for this thesis.

Thanks to the people who proof-read the thesis and manuscripts.

Simon Jönsson för alla timmar vi spenderat tillsammans i klassrummet, gymmet, squashhallen och soffan hemma. Vi har verkligen haft roligt tillsammans under vår grund- och forskarutbildning.

Familjen Ulin för många trevliga middagar, utflykter med barnen och nyårsfiranden. Ni bjuder alltid på innerlig värme, skratt och diverse konstigheter, som udda boktitlar och ordstäv ingen använt på 100 år.

Familjen Fast för all uppmuntran och stöd, roliga nyårsfiranden, filmkvällar och semester i husvagn och tält när temperaturen egentligen var för låg.

Andreas och Sara med era underbara familjer. Tack för alla uppmuntrande ord, bus med barnen, grillningar i skogen, och samtal om allt möjligt.

Ing-marie, Anders, mormor Irma och Annelie med familj. Ni välkomnade mig in i era familjer med öppet hjärta och jag har alltid känt mig accepterad som den jag är. Tack för många varma kramar, jular fulla med mat samt bad i varmare länder.

Mamma och pappa som från barnsben matat mig med mantrat att allting är möjligt. Ni har alltid uppmuntrat och stöttat mig för att nå lite längre, speciellt när det har blivit extra tufft. Utan allt ert arbete och slit skulle denna avhandling aldrig blivit skriven.

Helena, Elis, Ines och Benjamin för att vi får dela livets mest fantastiska stunder tillsammans. Ni har gjort de år vi delat till de bästa i mitt liv och jag tror de kommande kommer bli ännu bättre. Helena, tack för att du outtröttligt stöttat mig i 
allt men framför allt för att du är min bästa vän som jag kan dela mina innersta tankar med. 


\section{References}

1. Crivellato, E. \& Ribatti, D. Soul, mind, brain: Greek philosophy and the birth of neuroscience. Brain Res. Bull. 71, 327-336 (2007).

2. Clarke, E. \& O'Malley, C. D. The human brain and spinal cord : a historical study illustrated by writings from antiquity to the twentieth century. (Norman Pub, 1996).

3. Gross, C. G. Aristotle on the brain. The Neuroscientist 1, 245-250 (1995).

4. Martina, M. \& Taverna, S. Patch-clamp, methods and protocols. (Humana press, 2014).

5. Hille, B. Ion channels of excitable membranes. (Sinauer Associates, Inc, 2001).

6. Kandel, E., Schwartz, J., Jessell, T., Siegelbaum, S. \& Hudspeth, A. Principles of neural science. (The McGraw-Hill companies, 1991).

7. Hodgkin, A. L. \& Huxley, A. F. The dual effect of membrane potential on sodium conductance in the giant axon of Loligo. J. Physiol. 116, 497-506 (1952).

8. Hodgkin, A. L. \& Huxley, A. F. A quantitative description of membrane current and its application to conduction and excitation in nerve. 1952. Bull. Math. Biol. 52, 25-71; discussion 5-23 (1990).

9. Frolov, R. V., Bagati, A., Casino, B. \& Singh, S. Potassium channels in Drosophila: historical breakthroughs, significance, and perspectives. J. Neurogenet. 26, 275290 (2012). 
10. Shieh, C. C., Coghlan, M., Sullivan, J. P. \& Gopalakrishnan, M. Potassium channels: molecular defects, diseases, and therapeutic opportunities. Pharmacol. Rev. 52, 557-594 (2000).

11. Curran, M. E. et al. A molecular basis for cardiac arrhythmia: HERG mutations cause long QT syndrome. Cell 80, 795-803 (1995).

12. Peroz, D. et al. Kv7.1 (KCNQ1) properties and channelopathies. J. Physiol. 586, 1785-1789 (2008).

13. Hoshi, T., Zagotta, W. N. \& Aldrich, R. W. Shaker potassium channel gating. I: Transitions near the open state. J. Gen. Physiol. 103, 249-278 (1994).

14. Long, S. B., Tao, X., Campbell, E. B. \& MacKinnon, R. Atomic structure of a voltage-dependent $\mathrm{K}+$ channel in a lipid membrane-like environment. Nature 450, 376-382 (2007).

15. Jiang, Y. et al. X-ray structure of a voltage-dependent K+ channel. Nature $\mathbf{4 2 3 ,}$ 33-41 (2003).

16. Hartmann, H. A. et al. Exchange of conduction pathways between two related K+ channels. Science 251, 942-944 (1991).

17. Yellen, G., Jurman, M. E., Abramson, T. \& MacKinnon, R. Mutations affecting internal TEA blockade identify the probable pore-forming region of a $\mathrm{K}+$ channel. Science 251, 939-942 (1991).

18. Yool, A. J. \& Schwarz, T. L. Alteration of ionic selectivity of a K+ channel by mutation of the H5 region. Nature 349, 700-704 (1991). 
19. Morais-Cabral, J. H., Zhou, Y. \& MacKinnon, R. Energetic optimization of ion conduction rate by the K+ selectivity filter. Nature 414, 37-42 (2001).

20. Zhou, Y., Morais-Cabral, J. H., Kaufman, A. \& MacKinnon, R. Chemistry of ion coordination and hydration revealed by a $\mathrm{K}+$ channel-Fab complex at $2.0 \mathrm{~A}$ resolution. Nature 414, 43-48 (2001).

21. Cuello, L. G., Jogini, V., Cortes, D. M. \& Perozo, E. Structural mechanism of C-type inactivation in $\mathrm{K}(+)$ channels. Nature 466, 203-208 (2010).

22. Magidovich, E. \& Yifrach, O. Conserved gating hinge in ligand- and voltagedependent K+ channels. Biochemistry (Mosc.) 43, 13242-13247 (2004).

23. Seebohm, G. et al. Differential Roles of S6 Domain Hinges in the Gating of KCNQ Potassium Channels. Biophys. J. 90, 2235-2244 (2006).

24. Yifrach, O. \& MacKinnon, R. Energetics of pore opening in a voltage-gated $\mathrm{K}(+)$ channel. Cell 111, 231-239 (2002).

25. Hardman, R. M., Stansfeld, P. J., Dalibalta, S., Sutcliffe, M. J. \& Mitcheson, J. S. Activation gating of hERG potassium channels: S6 glycines are not required as gating hinges. J. Biol. Chem. 282, 31972-31981 (2007).

26. Elinder, F., Nilsson, J. \& Arhem, P. On the opening of voltage-gated ion channels. Physiol. Behav. 92, 1-7 (2007).

27. Tombola, F., Pathak, M. M. \& Isacoff, E. Y. How does voltage open an ion channel? Annu. Rev. Cell Dev. Biol. 22, 23-52 (2006). 
28. Lörinczi, É. et al. Voltage-dependent gating of KCNH potassium channels lacking a covalent link between voltage-sensing and pore domains. Nat. Commun. 6, 6672 (2015).

29. Hoshi, T., Zagotta, W. N. \& Aldrich, R. W. Biophysical and Molecular Mechanisms of Shaker Potassium Channel Inactivation. Science 250, 533-538 (1990).

30. Aggarwal, S. K. \& MacKinnon, R. Contribution of the S4 segment to gating charge in the Shaker K+ channel. Neuron 16, 1169-1177 (1996).

31. Seoh, S. A., Sigg, D., Papazian, D. M. \& Bezanilla, F. Voltage-sensing residues in the S2 and S4 segments of the Shaker K+ channel. Neuron 16, 1159-1167 (1996).

32. Jiang, Y., Ruta, V., Chen, J., Lee, A. \& MacKinnon, R. The principle of gating charge movement in a voltage-dependent $\mathrm{K}+$ channel. Nature 423, 42-48 (2003).

33. Larsson, H. P., Baker, O. S., Dhillon, D. S. \& Isacoff, E. Y. Transmembrane Movement of the Shaker K+ Channel S4. Neuron 16, 387-397 (1996).

34. Xu, Y., Ramu, Y. \& Lu, Z. A shaker K+ channel with a miniature engineered voltage sensor. Cell 142, 580-589 (2010).

35. Papazian, D. M. et al. Electrostatic interactions of S4 voltage sensor in Shaker K+ channel. Neuron 14, 1293-1301 (1995).

36. Gagnon, D. G. \& Bezanilla, F. A single charged voltage sensor is capable of gating the Shaker K+ channel. J. Gen. Physiol. 133, 467-483 (2009).

37. Pathak, M., Kurtz, L., Tombola, F. \& Isacoff, E. The cooperative voltage sensor motion that gates a potassium channel. J. Gen. Physiol. 125, 57-69 (2005). 
38. Keynes, R. D. \& Elinder, F. Modelling the activation, opening, inactivation and reopening of the voltage-gated sodium channel. Proc. $R$. Soc. Lond. B Biol. Sci. 265, 263-270 (1998).

39. Long, S. B., Campbell, E. B. \& Mackinnon, R. Voltage sensor of Kv1.2: structural basis of electromechanical coupling. Science 309, 903-908 (2005).

40. Fowler, P. W. \& Sansom, M. S. P. The pore of voltage-gated potassium ion channels is strained when closed. Nat. Commun. 4, 1872 (2013).

41. Smith-Maxwell, C. J., Ledwell, J. L. \& Aldrich, R. W. Role of the S4 in cooperativity of voltage-dependent potassium channel activation. J. Gen. Physiol. 111, 399-420 (1998).

42. Ledwell, J. L. \& Aldrich, R. W. Mutations in the S4 region isolate the final voltagedependent cooperative step in potassium channel activation. J. Gen. Physiol. 113, 389-414 (1999).

43. Zagotta, W. N., Hoshi, T. \& Aldrich, R. W. Shaker potassium channel gating. III: Evaluation of kinetic models for activation. J. Gen. Physiol. 103, 321-362 (1994).

44. Mannuzzu, L. M. \& Isacoff, E. Y. Independence and cooperativity in rearrangements of a potassium channel voltage sensor revealed by single subunit fluorescence. J. Gen. Physiol. 115, 257-268 (2000).

45. Chanda, B., Asamoah, O. K. \& Bezanilla, F. Coupling interactions between voltage sensors of the sodium channel as revealed by site-specific measurements. J. Gen. Physiol. 123, 217-230 (2004). 
46. MacKinnon, R., Aldrich, R. W. \& Lee, A. W. Functional stoichiometry of Shaker potassium channel inactivation. Science 262, 757-759 (1993).

47. Choi, K. L., Mossman, C., Aubé, J. \& Yellen, G. The internal quaternary ammonium receptor site of Shaker potassium channels. Neuron 10, 533-541 (1993).

48. Hoshi, T., Zagotta, W. N. \& Aldrich, R. W. Two types of inactivation in Shaker K+ channels: effects of alterations in the carboxy-terminal region. Neuron 7, 547556 (1991).

49. Cuello, L. G., Cortes, D. M. \& Perozo, E. The gating cycle of a K+ channel at atomic resolution. elife 6, (2017).

50. Larsson, H. P. \& Elinder, F. A conserved glutamate is important for slow inactivation in K+ channels. Neuron 27, 573-583 (2000).

51. Hoshi, T. \& Armstrong, C. M. C-type inactivation of voltage-gated K+ channels: pore constriction or dilation? J. Gen. Physiol. 141, 151-160 (2013).

52. Devaraneni, P. K. et al. Semisynthetic K+ channels show that the constricted conformation of the selectivity filter is not the C-type inactivated state. Proc. Natl. Acad. Sci. U. S. A. 110, 15698-15703 (2013).

53. Ogielska, E. M. et al. Cooperative subunit interactions in C-type inactivation of K channels. Biophys. J. 69, 2449-2457 (1995).

54. Panyi, G., Sheng, Z. \& Deutsch, C. C-type inactivation of a voltage-gated K+ channel occurs by a cooperative mechanism. Biophys. J. 69, 896-903 (1995). 
55. Armstrong, C. M. \& Bezanilla, F. Charge Movement Associated with the Opening and Closing of the Activation Gates of the Na Channels. J. Gen. Physiol. 63, 533552 (1974).

56. Tao, X., Lee, A., Limapichat, W., Dougherty, D. A. \& MacKinnon, R. A gating charge transfer center in voltage sensors. Science 328, 67-73 (2010).

57. Perozo, E., MacKinnon, R., Bezanilla, F. \& Stefani, E. Gating currents from a nonconducting mutant reveal open-closed conformations in Shaker K+ channels. Neuron 11, 353-358 (1993).

58. Olcese, R., Sigg, D., Latorre, R., Bezanilla, F. \& Stefani, E. A conducting state with properties of a slow inactivated state in a shaker $\mathrm{K}(+)$ channel mutant. J. Gen. Physiol. 117, 149-163 (2001).

59. Armstrong, C. M. Interaction of tetraethylammonium ion derivatives with the potassium channels of giant axons. J. Gen. Physiol. 58, 413-437 (1971).

60. Olcese, R., Latorre, R., Toro, L., Bezanilla, F. \& Stefani, E. Correlation between Charge Movement and Ionic Current during Slow Inactivation in Shaker K+ Channels. J. Gen. Physiol. 110, 579-589 (1997).

61. Bezanilla, F., Perozo, E., Papazian, D. M. \& Stefani, E. Molecular basis of gating charge immobilization in Shaker potassium channels. Science $\mathbf{2 5 4}, \mathbf{6 7 9 - 6 8 3}$ (1991).

62. Männikkö, R., Pandey, S., Larsson, H. P. \& Elinder, F. Hysteresis in the voltage dependence of HCN channels: conversion between two modes affects pacemaker properties. J. Gen. Physiol. 125, 305-326 (2005). 
63. Tilegenova, C., Cortes, D. M. \& Cuello, L. G. Hysteresis of KcsA potassium channel's activation- deactivation gating is caused by structural changes at the channel's selectivity filter. Proc. Natl. Acad. Sci. U. S. A. 114, 3234-3239 (2017).

64. Piper, D. R., Varghese, A., Sanguinetti, M. C. \& Tristani-Firouzi, M. Gating currents associated with intramembrane charge displacement in HERG potassium channels. Proc. Natl. Acad. Sci. U. S. A. 100, 10534-10539 (2003).

65. Bezanilla, F., Taylor, R. E. \& Fernández, J. M. Distribution and kinetics of membrane dielectric polarization. 1. Long-term inactivation of gating currents. J. Gen. Physiol. 79, 21-40 (1982).

66. Kuzmenkin, A., Bezanilla, F. \& Correa, A. M. Gating of the bacterial sodium channel, NaChBac: voltage-dependent charge movement and gating currents. J. Gen. Physiol. 124, 349-356 (2004).

67. Shirokov, R., Levis, R., Shirokova, N. \& Ríos, E. Two classes of gating current from L-type Ca channels in guinea pig ventricular myocytes. J. Gen. Physiol. 99, 863895 (1992).

68. Corbin-Leftwich, A. et al. Retigabine holds KV7 channels open and stabilizes the resting potential. J. Gen. Physiol. 147, 229-241 (2016).

69. Liu, B., Yao, J., Zhu, M. X. \& Qin, F. Hysteresis of gating underlines sensitization of TRPV3 channels. J. Gen. Physiol. 138, 509-520 (2011).

70. Villalba-Galea, C. A., Sandtner, W., Starace, D. M. \& Bezanilla, F. S4-based voltage sensors have three major conformations. Proc. Natl. Acad. Sci. U. S. A. 105, 17600-17607 (2008). 
71. Haddad, G. A. \& Blunck, R. Mode shift of the voltage sensors in Shaker K+ channels is caused by energetic coupling to the pore domain. J. Gen. Physiol. 137, 455-472 (2011).

72. Kamb, A., Iverson, L. E. \& Tanouye, M. A. Molecular characterization of Shaker, a Drosophila gene that encodes a potassium channel. Cell 50, 405-413 (1987).

73. Lippiat, J. Potassium channels Methods and protocols. (Humana press, 2009).

74. Gamper, N. Ion Channels, Methods and protocols. (Humana press, 2013).

75. van der Kamp, M. W., Shaw, K. E., Woods, C. J. \& Mulholland, A. J. Biomolecular simulation and modelling: status, progress and prospects. J. R. Soc. Interface 5 Suppl 3, S173-190 (2008).

76. Karplus, M. \& McCammon, J. A. Molecular dynamics simulations of biomolecules. Nat. Struct. Biol. 9, 646-652 (2002).

77. Das, R. \& Baker, D. Macromolecular modeling with rosetta. Annu. Rev. Biochem. 77, 363-382 (2008).

78. Broomand, A. \& Elinder, F. Large-scale movement within the voltage-sensor paddle of a potassium channel-support for a helical-screw motion. Neuron 59, 770-777 (2008).

79. Campos, F. V., Chanda, B., Roux, B. \& Bezanilla, F. Two atomic constraints unambiguously position the S4 segment relative to S1 and S2 segments in the closed state of Shaker K channel. Proc. Natl. Acad. Sci. U. S. A. 104, 7904-7909 (2007). 
80. DeCaen, P. G., Yarov-Yarovoy, V., Scheuer, T. \& Catterall, W. A. Gating charge interactions with the S1 segment during activation of a $\mathrm{Na}+$ channel voltage sensor. Proc. Natl. Acad. Sci. U. S. A. 108, 18825-18830 (2011).

81. Vargas, E., Bezanilla, F. \& Roux, B. In search of a consensus model of the resting state of a voltage-sensing domain. Neuron 72, 713-720 (2011).

82. Pathak, M. M. et al. Closing in on the resting state of the Shaker $\mathrm{K}(+)$ channel. Neuron 56, 124-140 (2007).

83. Henrion, U. et al. Tracking a complete voltage-sensor cycle with metal-ion bridges. Proc. Natl. Acad. Sci. U. S. A. 109, 8552-8557 (2012).

84. Jensen, M. $\emptyset$. et al. Mechanism of voltage gating in potassium channels. Science 336, 229-233 (2012).

85. Tytgat, J., Pauwels, P. J., Vereecke, J. \& Carmeliet, E. Flunarizine inhibits a highthreshold inactivating calcium channel (N-type) in isolated hippocampal neurons. Brain Res. 549, 112-117 (1991).

86. Sigg, D., Stefani, E. \& Bezanilla, F. Gating current noise produced by elementary transitions in Shaker potassium channels. Science 264, 578-582 (1994).

87. Hackos, D. H., Chang, T.-H. \& Swartz, K. J. Scanning the Intracellular S6 Activation Gate in the Shaker K+ Channel. J. Gen. Physiol. 119, 521-531 (2002).

88. Soler-Llavina, G. J., Chang, T.-H. \& Swartz, K. J. Functional interactions at the interface between voltage-sensing and pore domains in the Shaker K(v) channel. Neuron 52, 623-634 (2006). 
89. Ortega-Sáenz, P., Pardal, R., Castellano, A. \& López-Barneo, J. Collapse of conductance is prevented by a glutamate residue conserved in voltagedependent K(+) channels. J. Gen. Physiol. 116, 181-190 (2000).

90. Armstrong, C. M. \& Hoshi, T. $\mathrm{K}^{+}$channel gating: C-type inactivation is enhanced by calcium or lanthanum outside. J. Gen. Physiol. 144, 221-230 (2014).

91. Ottosson, N. E., Liin, S. I. \& Elinder, F. Drug-induced ion channel opening tuned by the voltage sensor charge profile. J. Gen. Physiol. 143, 173-182 (2014).

92. Börjesson, S. I. \& Elinder, F. An electrostatic potassium channel opener targeting the final voltage sensor transition. J. Gen. Physiol. 137, 563-577 (2011). 


\section{Papers}

The papers associated with this thesis have been removed for copyright reasons. For more details about these see:

http://urn.kb.se/resolve?urn=urn:nbn:se:liu:diva-146967 